\title{
Article \\ Biostratigraphy and Paleoenvironmental Reconstruction at the Gebel Nezzazat (Central Sinai, Egypt): A Paleocene Record for the Southern Tethys
}

\author{
Atef M. Kasem ${ }^{1}$, Mahmoud Faris ${ }^{2}$, Luigi Jovane ${ }^{3, *}$, Taysir Abdelhamid Ads ${ }^{1}$, Fabrizio Frontalini ${ }^{4}$ (D) \\ and Amr S. Zaky ${ }^{5,6, *(D)}$ \\ 1 Geology Department, Faculty of Science, Damanhour University, Damanhour 22511, Egypt; \\ kasematef@sci.dmu.edu.eg (A.M.K.); tayseeradss@gmail.com (T.A.A.) \\ 2 Geology Department, Faculty of Science, Tanta University, Tanta 31527, Egypt; mhmfaris@yahoo.com or \\ mahmoud.ahmed1@science.tanta.edu.eg \\ 3 Instituto Oceanográfico da Universidade de São Paulo, Praça do Oceanográfico, 191, \\ São Paulo 05508-120, Brazil \\ 4 Dipartimento di Scienze Pure e Applicate (DiSPeA), Università degli Studi di Urbino "Carlo Bo", \\ 61029 Urbino, Italy; fabrizio.frontalini@uniurb.it \\ 5 Institute of Geological Sciences, Oeschger Centre for Climate Change Research, University of Bern, \\ 3012 Bern, Switzerland \\ 6 Geology Department, Faculty of Science, Menoufia University, Shebin El-Kom 32511, Egypt \\ * Correspondence: jovane@ups.br (L.J.); amr.zaky@geo.unibe.ch or amrsaid86@science.menofia.edu.eg (A.S.Z.)
}

\section{check for}

updates

Citation: Kasem, A.M.; Faris, M.; Jovane, L.; Ads, T.A.; Frontalini, F.; Zaky, A.S. Biostratigraphy and

Paleoenvironmental Reconstruction at the Gebel Nezzazat (Central Sinai, Egypt): A Paleocene Record for the Southern Tethys. Geosciences 2022, 12, 96. https://doi.org/10.3390/ geosciences 12020096

Academic Editors: Jesus Martinez-Frias and Rossana Sanfilippo

Received: 24 January 2022 Accepted: 17 February 2022 Published: 20 February 2022

Publisher's Note: MDPI stays neutral with regard to jurisdictional claims in published maps and institutional affiliations.

Copyright: (C) 2022 by the authors. Licensee MDPI, Basel, Switzerland. This article is an open access article distributed under the terms and conditions of the Creative Commons Attribution (CC BY) license (https:// creativecommons.org/licenses/by/ $4.0 /)$.

\begin{abstract}
The variations in assemblages of calcareous nannofossils are tracked in the Dakhla and Tarawan Formations exposed at Gebel Nezzazat (central Sinai, Egypt). Five calcareous nannofossil biozones, namely NP2/3, NP4, NP5, NP6, and NP7/8 are identified. A distinct marker bed related to the Latest Danian Event (LDE) occurs within the Dakhla Fm. The earliest representative of fasciculiths, Lithoptychius schmitzii, first occurs just below the LDE distinct bed and is followed by the Los of Diantholitha alata, D. mariposa, L. varolii, L. felis, and L. collaris. The abundance of calcareous nannofossils drops within the LDE distinctive bed. The base of Selandian Stage is here approximated at the base of Zone NP5 in concurrence with a sudden drop in the abundance of calcareous nannofossils. No considerable lithological changes are noted across this transition. The absence of subsequent occurrences of L. ulii, L. janii, L. billii, and L. stegostus suggest inconsistent lowest occurrences (Los) of these taxa, insufficient sampling resolution, and/or a hiatus. The base of Thanetian is approximated with the base of Zone NP7/8 in the topmost of Dakhla Fm. No considerable changes in calcareous nannofossil assemblages are associated in correspondence to this transition except the $\mathrm{LO}$ of D. mohleri, lowest continuous occurrence (LctO) of Bomolithus megastypus, and the increase in abundance of Heliolithus kleinpellii as well as a sudden drop in abundance within Zone NP7/8. The variations in calcareous nannofossil assemblages at Gebel Nezzazat suggest prevailing warm-water and oligotrophic conditions during the Paleocene and particularly along the Danian Stage that are interrupted by minor fluctuations in paleoclimatic conditions. In particular, the Danian-Selandian transition marks a decrease in warm and oligotrophic conditions that persisted along the Selandian Stage. The Selandian-Thanetian transition shows an increase of warm and oligotrophic conditions prevailed in the Thanetian record. The sudden decrease in abundance of calcareous nannofossils in both the Selandian and Thanetian is likely resulted from an increase in dissolution of carbonates rather than variations in the paleotemperature and/or paleofertility.
\end{abstract}

Keywords: nezzazat; sinai; calcareous nannofossils; danian/selandian; selandian/thanetian; paleoclimate

\section{Introduction}

The Paleocene Epoch (Series) has been formally divided into Danian, Selandian, and Thanetian Stages [1,2]. This epoch was characterized by short and extremely warm episodes 
(known as hyperthermal events) associated with sedimentological and isotopic changes as well as variations in calcareous nannofossil assemblages [3-9]. These Paleocene events comprise the Late Danian Event (LDE) [10-13]; the Danian/Selandian (D/S) transition event [14,15]; the early-late Paleocene event (ELPE, [3]), also known as the mid-Paleocene biotic event (MPBE, [4]); and likely part of the long-lasting environmental disruption during the Paleocene (i.e., the Selandian-Thanetian Transition Event, STTE, [8]).

It is hypothesized that this interval is the consequence of a revolution of the bottom water conditions following the beginning of a deep-water connection in the South Atlantic Ocean (Figure 1), when the Atlantic Ocean Circulation increasingly substitutes the Tethys circum-equatorial oceanic circulation [16]. Moreover, some studies attributed the sharp climatic anomalies in the early Paleogene to drastic changes in paleocirculation [16].

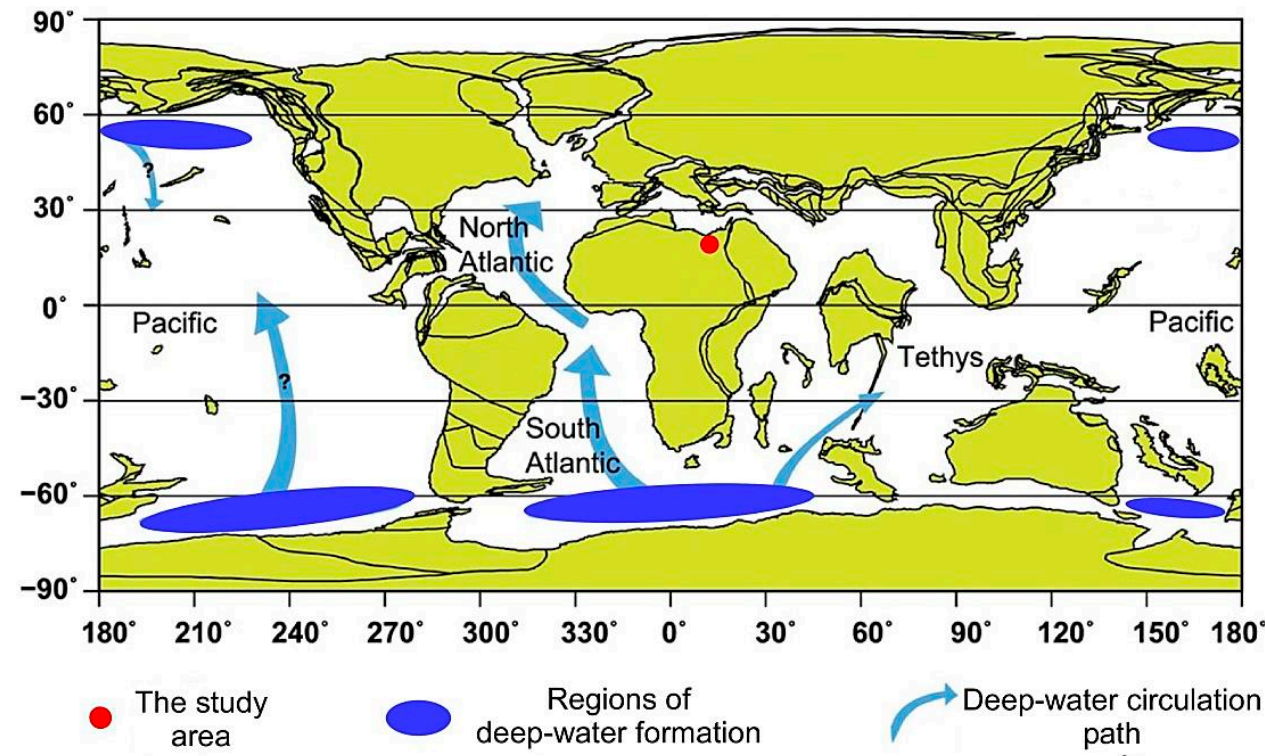

Figure 1. A paleogeographic map indicates the paleocirculation during the early Paleogene (modified after [16]).

A hiatus characterized the Selandian Stage at its type locality in Denmark [17]; consequently, intensive efforts have been made to define the GSSP (Global Stratotype Section and Point) for the base of the Selandian that was formally ratified at Itzurun Beach in Zumaia, Basque Country, northern Spain [2,15]. At Zumaia, the base of the Selandian coincides with the change from the limestone-dominated Aitzgorri Fm. to the marl-dominated Itzurun Fm. The base of the Selandian at Zumaia is coincident with the second radiation of Fasciculithus and can be approximated to the highest common occurrence (HCO) of the Braarudosphaera bigelowii and is close to the base of Zone NP5 [14,15,18,19]. The base of Thanetian was originally defined at the base of Thanet Fm. in England [20]. Later, the GSSP for the base of the Thanetian Stage has been also formally placed at Itzurun Beach in Zumaia, Basque Country, northern Spain, and positioned at the base of Chron C26n [2,15].

The Paleocene well-exposed outcrops in Egypt (southern Tethys) provide good records of paleobiological and sedimentological variations throughout this epoch [6,10,12,21-25]. Consequently, many Paleocene sequences in Egypt were subjected to intense biostratigraphic investigations based on calcareous nannofossils [26,27].

The main objectives of the present study are to recognize the variations in lithological and calcareous nannofossil assemblages at Gebel Nezzazat (central Sinai, Egypt), to detect the different stage boundaries biostratigraphically, to compare the results with available data from other sections, and to provide a paleoenvironmental and paleoclimatic reconstruction throughout the Danian-Thanetian interval at the southern Tethys. 


\section{Geological Setting and Stratigraphical Framework}

The study section, Gebel Nezzazat $\left(28^{\circ} 47^{\prime} 45.4^{\prime \prime} \mathrm{N}\right.$ and $\left.33^{\circ} 14^{\prime} 9.79^{\prime \prime} \mathrm{E}\right)$, is located in West Central Sinai, Egypt (Figure 2). The Paleocene interval exposing at Gebel Nezzazat is divided into the Dakhla Fm. that underlies the Tarawan Fm.

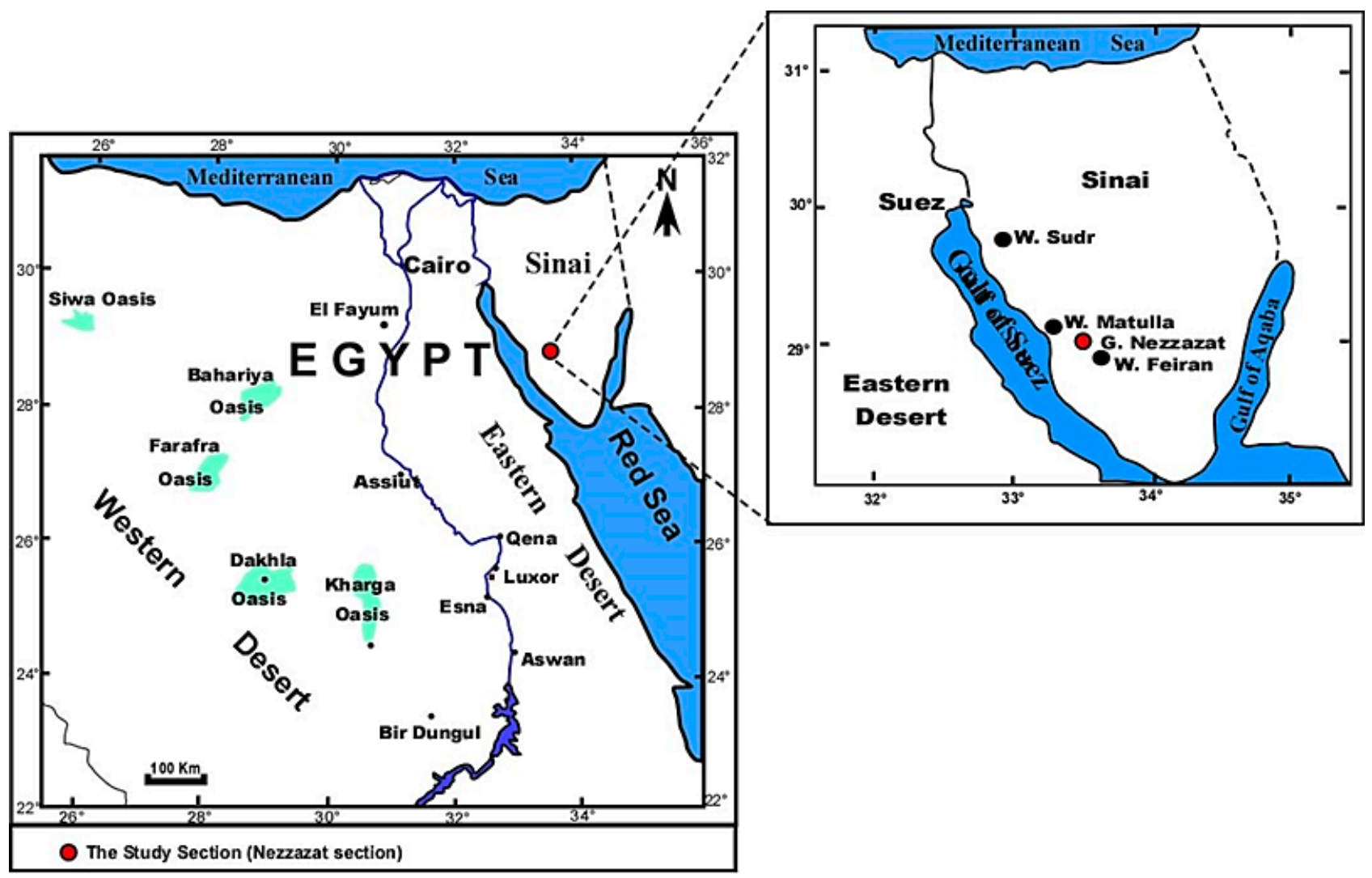

Figure 2. A map shows the location of the Gebel Nezzazat section (central Sinai, Egypt).

\subsection{Lithostratigraphy}

\subsubsection{The Dakhla Formation}

The type section of the Dakhla Fm. is located at North of Mut, Dakhla Oasis [28]; it overlies the Duwi Fm. and underlies the Tarawan Fm. It is $225 \mathrm{~m}$ thick of shales (yellowish to grayish), marls, and clays intercalated with calcareous sandy and silty beds [29] and is assigned to Danian-Selandian. At Gebel Nezzazat, $16 \mathrm{~m}$ of the Dakhla Fm. is considered for this study, and it consists of calcareous shale (yellowish, black, gray to dark gray) and shaly marl. The thickness and composition of the Dakhla Fm. is shown in Figure 3. A distinct marker bed within the Dakhla Fm. has been recorded in different sections in Egypt. It was referred to the D/S transition [30], "Neo-Duwi"-event [24,31], the 'El-Qreiya event' [32], and Qreiya Beds [33]. It has been assigned to the base of the Selandian [10-12,25,30-32,34-37]. However, later investigations uncovered that this bed is older than the D/S boundary, and, therefore, this bed has been known as the "Latest Danian Event" (LDE) [25]. Soliman et al. [33] documented the Qreiya Beds at Gebel Nezzazat as four alternating shale beds that are thinly laminated, organic-rich, and phosphatic. 


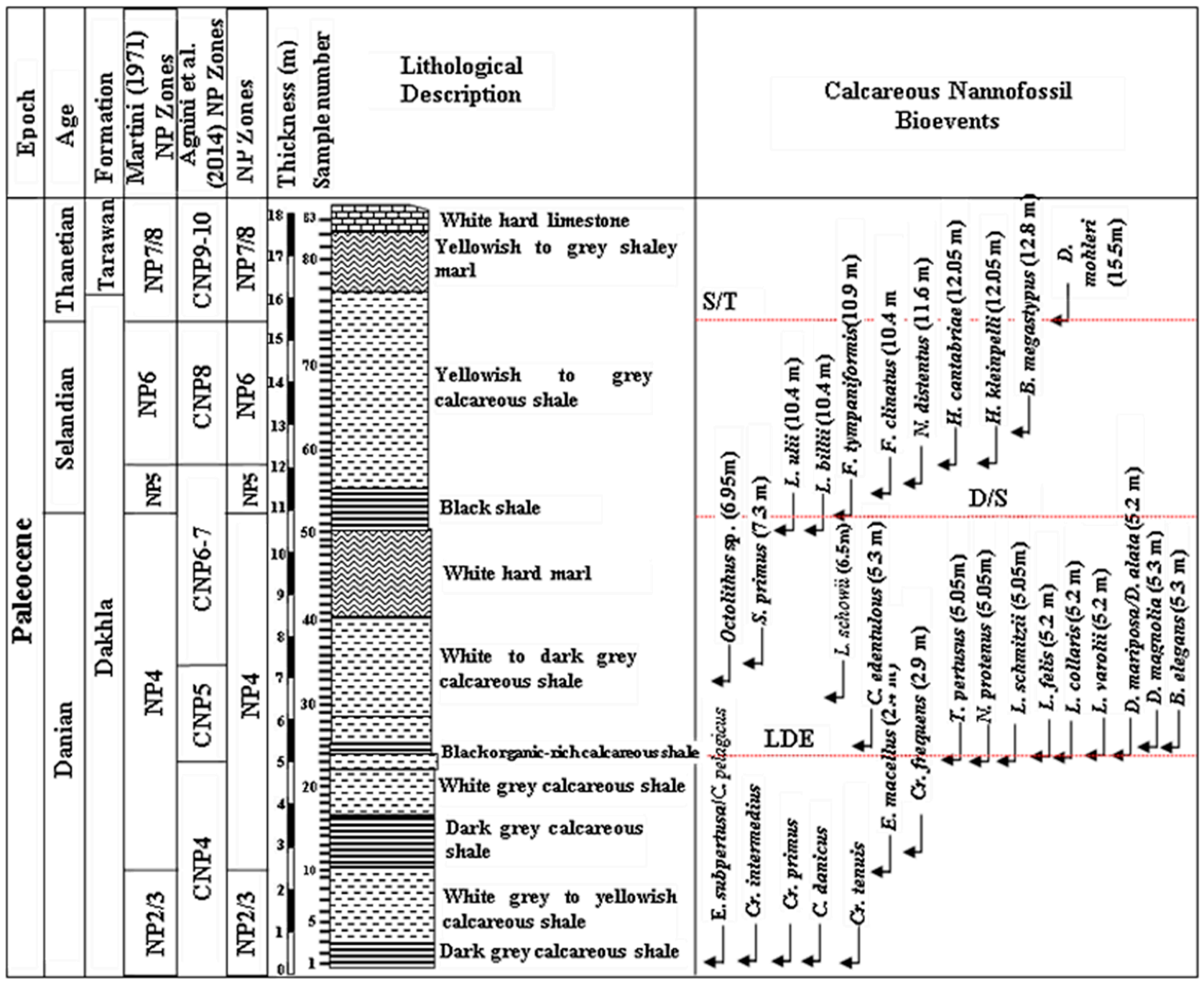

Figure 3. Stratigraphic section with important Paleocene calcareous nannofossil bioevents at Gebel Nezzazat section.

\subsubsection{The Tarawan Formation}

The Gebel Tarawan at Kharga Oasis, Western Desert, hosts the type locality of the Tarawan Fm. At this locality, the Tarawan Fm. consists of grayish to yellowish and lightgray fossiliferous, argillaceous limestone [29]. The lower part of this formation is marly and intercalated with thin beds of shale and clay. It grades upward into white chalky limestone and hard siliceous limestone [29]. About $2 \mathrm{~m}$ of this formation is included in the present study and consists of yellowish to gray shaly marl that upgrades to white limestone (Figure 3). Inconsistencies in calcareous nannofossils dating of the base of the Tarawan Fm. were documented and probably resulted from changes in relative water depths during its deposition among different areas [26,27].

\section{Materials and Methods}

\subsection{Calcareous Nannofossils}

Eighty-three bulk Samples were collected and examined from the Paleocene succession at Gebel Nezzazat. Smear slides of dry sediments were prepared by scraping a $0.1 \mathrm{mg}$ of raw materials into a beaker, to which $10 \mathrm{~mL}$ of distilled water was then added. The sediments were dispersed to ensure an equal amount of sediment per unit area of coverslip. A $0.25 \mathrm{~mL}$ of the suspension was smeared onto the surface of a $22 \times 22 \mathrm{~mm}$ coverslips and dried rapidly on a hot plate. After drying the suspension, the coverslip was fixed on a glass slide 
using D.P.X. adhesive. The slides were investigated under Euromex iScope microscope at $1250 \times$ magnification. A quantitative analysis was attempted, where calcareous nannofossil specimens were counted in 50 fields of view to recognize the relative abundances of species. The fragments of Thoracosphaera greater than $4 \mu \mathrm{m}$ were also considered as a complete specimen [38]. No evidence of overgrowth was noted in this study.

Calcareous nannofossils are useful tool for high-resolution biozonation and correlation of Cenozoic sediments [39-47]. The "Standard" Zonation Scheme of [39] for the Paleocene has been adopted in the present study with slight modifications. We also followed the proposal of [48] that combines Zones NP2 and NP3 and Zones NP7 and NP8 in this study. Abbreviations used in the present study include LO for the "Lowest Occurrence", LCtO for the "Lowest Continuous Occurrence", LCO for the "Lowest Common Occurrence", HCO for the "Highest Common Occurrence", and HO for "Highest Occurrence".

\subsection{Paleoecological Inferences}

Variations in calcareous nannofossil assemblages are a significant tool for tracking the paleoenvironmental changes. These phytoplankton organisms are controlled by a set of water parameters such as light, temperature, nutrient availability, ocean currents, surface water stratification, and salinity [4,49-51]. The temperature is an important factor controlling the distribution of calcareous nannofossils [51]. Cosmopolitan taxa tolerate change in temperature and are common in the low and the high-latitude areas. The distribution of coccolithophores is affected by the light and restricted to the photic zone. The productivity change is another parameter influencing the distribution of calcareous nannofossils. In modern oceans, high concentration of nutrients occurs either in upwelling areas or in areas with high input of rivers [51]. Oligotrophic conditions with low-nutrient levels; stable, well-stratified surface waters; a deep thermocline; or warm water conditions are sufficient for radiation of coccoliths in recent settings [38,51,52]. Calcareous nannofossil taxa that dominate under oligotrophic conditions are viewed as K-mode specialists. In contrast, eutrophic conditions are marked by high-nutrient levels, well-mixed surface waters, and low diversity of planktons dominated by mesotrophic or eutrophic taxa [50,53]. Calcareous nannofossil taxa that flourish in eutrophic cool water and active conditions are viewed as r-mode specialists [54].

The paleoenvironmental settings control the variation in productivity must be taken into consideration, where open ocean areas are characterized by oligotrophic conditions and continental shelves are characterized by mesotrophic to eutrophic conditions [55]. Furthermore, some calcareous nannofossil taxa increase in size and decrease in diversity with increasing nutrient concentrations [51]. Moreover, oligotrophic forms dominate warmwater assemblages, whereas eutrophic taxa are more common in cold-water conditions; the effect of paleotemperature cannot be differentiated from the influence of paleofertility [50]. In addition, the ecological preferences of a certain species possibly changed through time [56]. Other factors might control the distribution of calcareous nannofossils such as salinity, turbidity, and rate of sedimentation that might not be sufficient for the fossilization of some forms $[57,58]$.

Several calcareous nannofossil species do not have well-known latitudinal preference and paleofertility affinity. Despite this, for paleoecological inferences, most of the calcareous nannofossils could be, whenever possible, allocated into groups attributed to their environmental affinities in order to infer the paleotemperature and/or the trophic variations of surface waters [3,8,38,56,59-65].

Thus, according to the aforementioned literature, the species that have certain paleoecological affinities and/or paleofertility are used in this study (Table 1) to infer the changes in the paleotemperature and paleofertility. 
Table 1. The calcareous nannofossil taxa used for paleoecological inferences in the present study.

\begin{tabular}{|c|c|c|c|c|c|}
\hline Warm-Water Taxa & Cold-Water Taxa & Eutrophic Taxa & $\begin{array}{l}\text { Mesotrophic } \\
\text { Taxa }\end{array}$ & $\begin{array}{c}\text { Meso-Oligotrophic } \\
\text { Taxa }\end{array}$ & Oligotrophic Taxa \\
\hline Bomolithus spp. & $\begin{array}{l}\text { Arkhangelskiella } \\
\text { cymbiformis }\end{array}$ & $\begin{array}{l}\text { Arkhangelskiella } \\
\text { cymbiformis }\end{array}$ & $\begin{array}{l}\text { Cruciplacolithus } \\
\text { spp. }\end{array}$ & Heliolithus spp. & Bomolithus spp. \\
\hline $\begin{array}{l}\text { Coccolithus } \\
\text { pelagicus }\end{array}$ & Blackites spp. & Blackites spp. & Prinsius spp. & - & $\begin{array}{l}\text { Coccolithus } \\
\text { pelagicus }\end{array}$ \\
\hline $\begin{array}{c}\text { Cylindralithus } \\
\text { sculptus }\end{array}$ & Chiasmolithus spp. & Chiasmolithus spp. & T. tovae & - & $\begin{array}{l}\text { Cylindralithus } \\
\text { sculptus }\end{array}$ \\
\hline Discoaster spp. & $\begin{array}{l}\text { Cruciplacolithus } \\
\text { spp. }\end{array}$ & $\begin{array}{l}\text { Cruciplacolithus } \\
\text { spp. }\end{array}$ & Toweius eminens & - & Discoaster spp. \\
\hline Discoasteroides & Eiffellithus spp. & $\begin{array}{l}\text { Neochiastozygus } \\
\text { spp. }\end{array}$ & - & - & Discoasteroides \\
\hline Ericsonia subpertusa & Markalius inversus & Prinsius spp. & - & - & Eiffellithus spp. \\
\hline Fasciculithus spp. & $\begin{array}{l}\text { Neococolithus } \\
\text { protens }\end{array}$ & T. saxea & - & - & Ericsonia subpertusa \\
\hline $\begin{array}{l}\text { Heliolithus } \\
\text { kleinpellii }\end{array}$ & Prinsius spp. & $\begin{array}{l}\text { Zeugrhabdotus } \\
\text { sigmoides }\end{array}$ & - & - & Fasciculithus spp. \\
\hline $\begin{array}{c}\text { Lithraphidites } \\
\text { carniolensis }\end{array}$ & Toweius tovae & - & - & - & $\begin{array}{c}\text { Heliolithus } \\
\text { kleinpellii }\end{array}$ \\
\hline M. prinsii & Toweius eminens & - & - & - & $\begin{array}{l}\text { Lithraphidites } \\
\text { carniolensis }\end{array}$ \\
\hline Micula murus & $\begin{array}{l}\text { Zeugrhabdotus } \\
\text { sigmoides }\end{array}$ & - & - & - & Octolithus spp. \\
\hline Pontosphaera spp. & - & - & - & - & $\begin{array}{l}\text { Prediscosphaera } \\
\text { cretacea }\end{array}$ \\
\hline Rhomboaster spp. & - & - & - & - & Rhomboaster spp. \\
\hline Sphenolithus spp. & - & - & - & - & Sphenolithus spp. \\
\hline $\begin{array}{c}\text { Thoracosphaera } \\
\text { saxea }\end{array}$ & - & - & - & - & Tribrachiatus spp. \\
\hline $\begin{array}{c}\text { Thoracosphaera } \\
\text { operculata }\end{array}$ & - & - & - & - & $\begin{array}{c}\text { Watznaueria } \\
\text { barnesae }\end{array}$ \\
\hline Tribrachiatus spp. & - & - & - & - & - \\
\hline $\begin{array}{c}\text { Watznaueria } \\
\text { barnesae }\end{array}$ & - & - & - & - & - \\
\hline
\end{tabular}

\section{Results}

\subsection{Lithostratigraphy}

The present study recorded a distinct marker bed within the Dakhla Fm. at Gebel Nezzazat: about $30 \mathrm{~cm}$ of dark gray organic-rich calcareous shale (Samples 35-40) (Figure 3). It is assigned to the Danian Stage, as inferred from calcareous nannofossil data. In this study, the Tarawan Fm. is assigned to the Thanetian Stage, and it conformably overlies the Dakhla Fm., as inferred from calcareous nannofossil data (Figure 3).

\subsection{Biostratigraphy}

Five calcareous nannofossil zones, from older to younger, Cruciplacolithus tenuis Zone (NP2/3), Ellipsolithus macellus Zone (NP4), Fasciculithus tympaniformis Zone (NP5), Heliolithus kleinpellii Zone (NP6), and Discoaster mohleri Zone (NP7/8), are recognized. The Zones NP2/3, NP4, NP5, and NP6 are assigned to the Danian Stage, while the Zone NP7/8 is assigned to the Selandian Stage.

The distribution of the recognized biozones associated with the important calcareous nannofossil bioevents is presented in Figure 3. The counts and ranges of the different calcareous nannofossil species defined in the present study are shown in the Supplementary Table S1. In addition, micrographs for most of the recognized calcareous nannofossil taxa of the present study are shown in Schemes 1 and 2. 


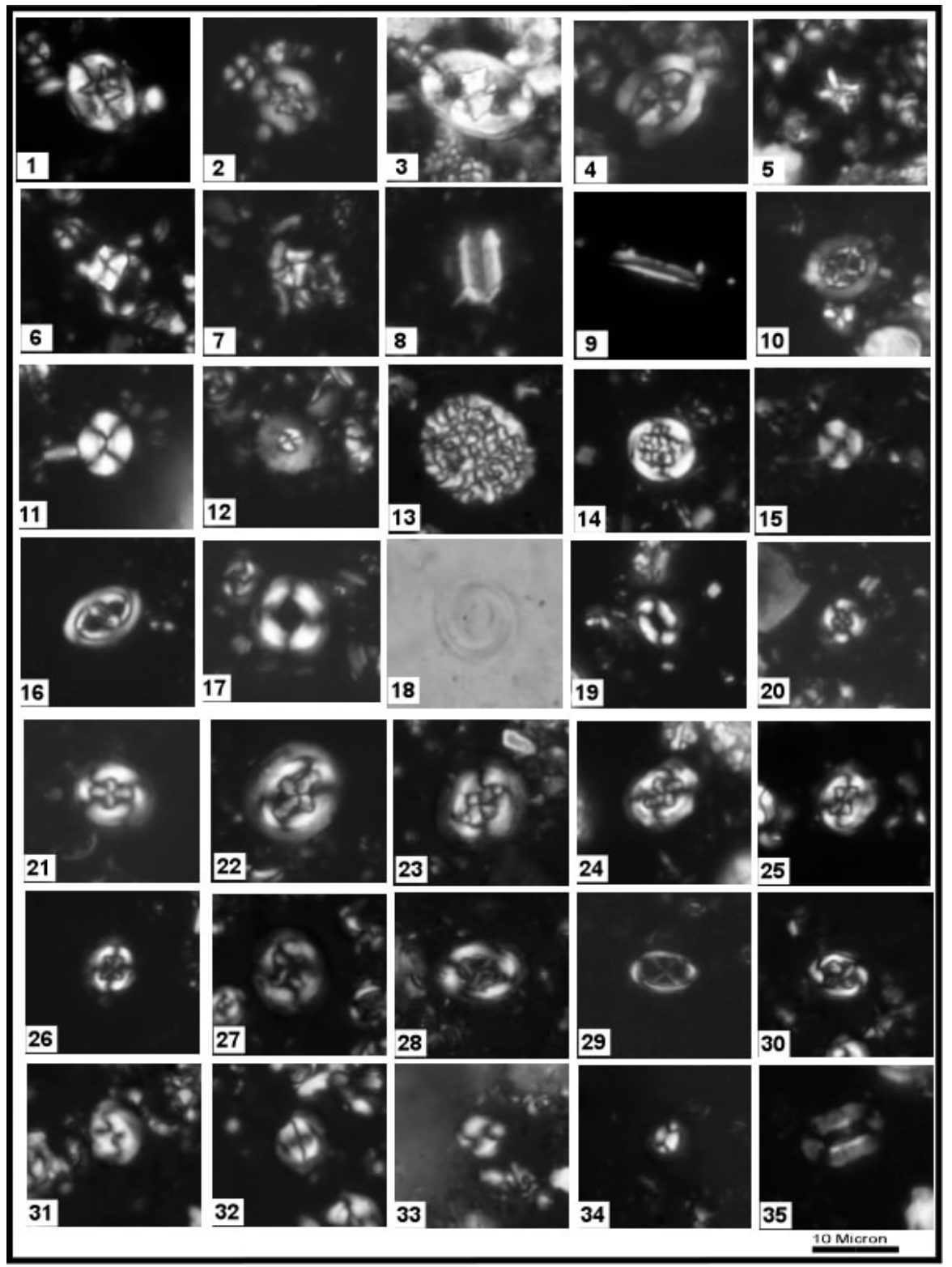

Scheme 1. 1 Eiffellithus turriseiffelii. Sample No. 3, Zone NP2/3. 2 Retecapsa crenulata. Sample No. 37, Zone NP4. 3 Gorkaea pseudanthophorus. Sample No. 6, Zone NP2/3. 4 Arkhangelskiella cymbiformis. Sample No. 7, Zone NP2/3. 5, 6 Micula decussata, 5, Sample No. 6, Zone NP2/3; 6, Sample No. 3, Zone NP2/3. 7 Micula swastika. Sample No. 6, Zone NP2/3. 8 Schyphosphaera sp. Sample No. 41, Zone NP4. 9 Lithraphidites carniolensis. Sample No. 4, Zone NP2/3. 10 Prediscosphaera cretacea. Sample No. 3, Zone NP2/3. 11 Watznaueria barnesiae. Sample No. 3, Zone NP2/3. 12 Markalius inversus. Sample No. 7, Zone NP2/3. 13 Thoracosphaera operculata. Sample No. 41, Zone NP4. 14 Thoracosphaera saxea. Sample No. 24, Zone NP4. 15 Cylindralithus sculptus. Sample No. 23, Zone NP4. 16 Zeugrhabdotus sigmoides. Sample No. 23, Zone NP4. 17, 18 Ericsonia subpertusa. 17, Sample No. 35, Zone NP4; 18, Sample No. 37, Zone NP4. 19 Coccolithus pelagicus. Sample No. 2, Zone NP2/3. 20 Cruciplacolithus primus. Sample No. 35, Zone NP4. 21, 22 Cruciplacolithus intermedius. 21, Sample No. 35, Zone NP4; 22 Sample No. 23, Zone NP4. 23 Cruciplacolithus tenuis. Sample No. 44, Zone NP4. 24, 25 Cruciplacolithus edwardsii. Sample No. 4, Zone NP2/3. 26, 27 Chiasmolithus danicus. 26, Sample No. 3, Zone NP2/3; 27, Sample No. 66, Zone NP6. 28 Chiasmolithus bidens. Sample No. 36, Zone NP4. 29, 30 Neochiastozygus modestus. 29, Sample No. 2, Zone NP2/3; 30, Sample No. 66, Zone NP6. 31 Toweius eminens. Sample No. 66, Zone NP6. 32, 33 Toweius pertusus. 32, Sample No. 62, Zone NP6; 33, Sample No. 40, Zone NP4. 34 Prinsius martini. Sample No. 36, Zone NP4. 35 Ellipsolithus macellus. Sample No. 2, Zone NP2/3. 


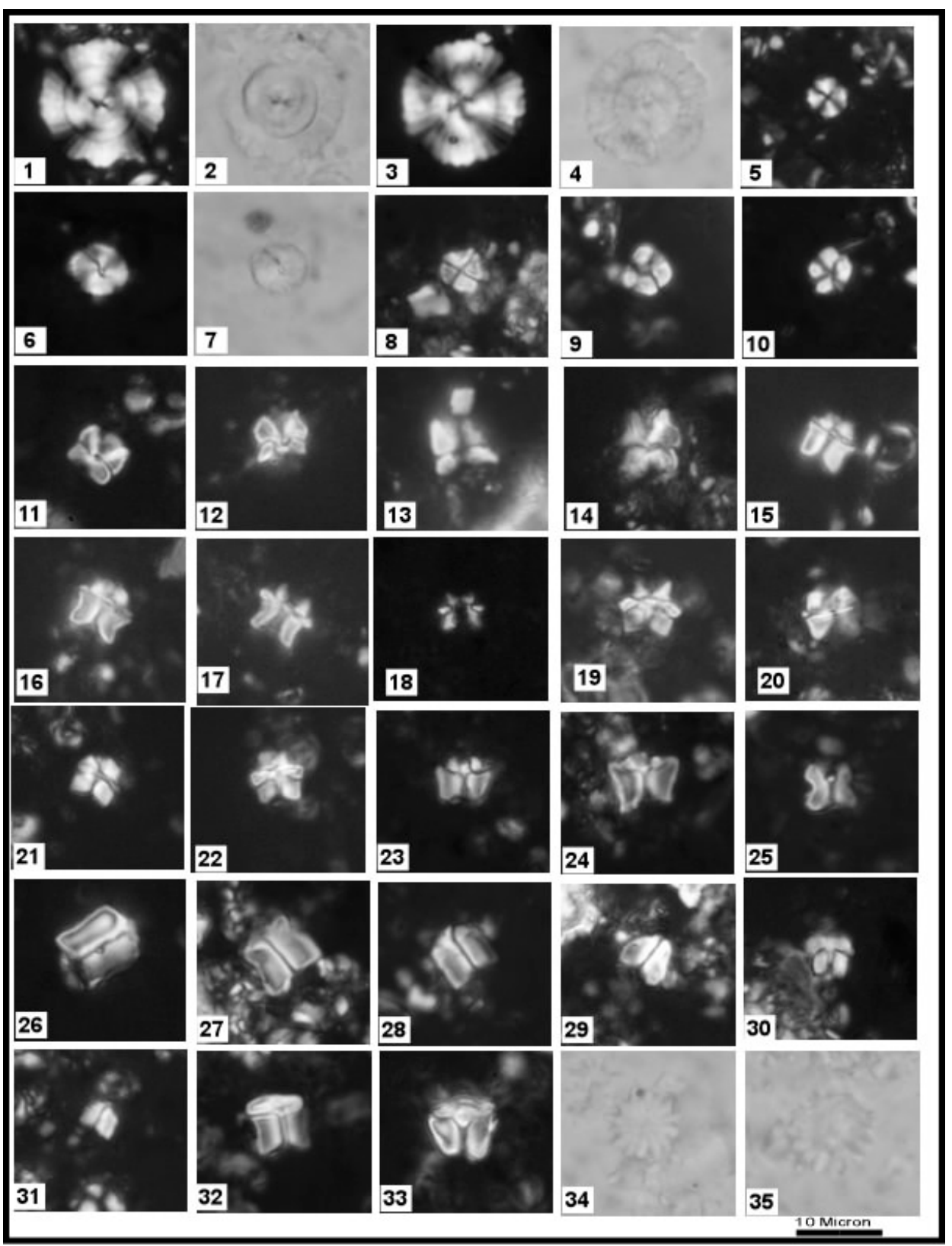

Scheme 2. 1-4 Heliolithus kleinpellii. 1, 2, Sample No. 62, Zone NP6; 3, 4, Sample No. 77, Zone NP7/8. 5-7 Bomolithus conicus. 5, Sample No. 50, Zone NP4; 6, 7, Sample No. 62, Zone NP6. 8 Octolithus sp. Sample No. 44, Zone NP4. 9, 10 Sphenolithus primus. 9, Sample No. 40, Zone NP4; 10, Sample No. 44, Zone NP4. 11, 12 Diantholitha magnolia. 11, Sample No. 41, Zone NP4; 12, Sample No. 32, Zone NP4. 13 Diantholitha alata. Sample No. 33, Zone NP4. 14 Diantholitha mariposa. Sample No. 24, Zone NP4. 15, 16 Lithoptychius chowii. 15, Sample No. 32, Subzone NP4a; 16, Sample No. 34, Subzone NP4a. 17, 18 Lithoptychius schmitzii. 17, Sample No. 32, Zone NP4; 18, Sample No. 44, Zone NP4. 19, 22 Lithoptychius felis. Sample No. 37, Zone NP4. 20, 21 Lithoptychius varolii. 20, Sample No. 36, Zone NP4; 21, Sample No. 40, Zone NP4. 23, 24 Lithoptychius ulii. 23 Sample No. 44, Zone NP4; 24, Sample No. 41, Zone NP4. 25 Lithoptychius vertebratoides. Sample No. 37, Zone NP4. 26 Fasciculithus involutus. Sample No. 62, Zone NP6. 27 Lithoptychius billii, Sample No. 62, Zone NP6. 28, 31 Fasciculithus tympaniformis. 28, Sample No. 62, Zone NP6; 31, Sample No. 62, Zone NP6. 29 Fasciculithus clinatus. Sample No. 77, Zone NP7/8. 30, 32 Lithoptychius janii. 30, Sample No. 62, Zone NP6; 32, Sample No. 50, Zone NP4. 33 Lithoptychius pileatus. Sample No. 66, Zone NP6. 34, 35 Discoaster mohleri. Sample No. 78, Zone NP7/8. 
- $\quad$ Cruciplacolithus tenuis Zone (NP2/3)

It was initially introduced by [66], and later, ref. [48] emended it to span from the LO of the species Cruciplacolithus tenuis to the LO of the species Ellipsolithus macellus (2.4 m). In this study, Zones NP2 and NP3 are combined. This zone covers an area about $2.4 \mathrm{~m}$ thick within the Dakhla Fm. (Figure 3).

- $\quad$ Ellipsolithus macellus Zone (NP4)

This zone was introduced by [39] to cover from the LO of species E. macellus (2.4 m) to the LO of species Fasciculithus tympaniformis (10.9 m). At Gebel Nezzazat, this zone covers an area about $8.5 \mathrm{~m}$ thick in the Dakhla Fm. (Figure 3).

- $\quad$ Fasciculithus tympaniformis Zone (NP5)

It was first introduced to cover the interval from the LO of species F. tympaniformis $(10.9 \mathrm{~m})$ to the LO of species Heliolithus kleinpellii (12.05 m) [67]. At Gebel Nezzazat, this zone is about $1.25 \mathrm{~m}$ thick in the Dakhla Fm. (Figure 3).

- $\quad$ Heliolithus kleinpellii Zone (NP6)

This zone was introduced to span between the LOs of Heliolithus kleinpellii (12.05 m) and Discoaster mohleri $(15.5 \mathrm{~m})$ [67]. In the studied section, it covers an area about $3.5 \mathrm{~m}$ thick in the Dakhla Fm. (Figure 3).

- $\quad$ Discoaster mohleri Zone (NP7/8)

This zone was originally proposed by [68] and later was emended by [48] to span from the LO of D. mohleri $(15.5 \mathrm{~m})$ to the LO of Discoaster multiradiatus. It covers an area $2.5 \mathrm{~m}$ thick and extends from the uppermost Dakhla Fm. to the lowermost Tarawan Fm. at Gebel Nezzazat (Figure 3).

\section{Discussion}

\subsection{Biostratigraphical Remarks and Calcareous Nannofossil Zones}

The Cruciplacolithus tenuis Zone (NP2/3) is comparable to Subzone CP1b plus Zone CP2 of [43]. The base of Zone NP2 of [39] is higher than that given by most authors as a consequence of the taxonomic disputes related to $C$. tenuis $[48,69,70]$. In this study, C. tenuis includes specimens that have "feet" where their axial crossbars meet the brim. Some authors [46-48] excluded $C$. danicus from being a zonal guide as a consequence of the discrepancies related to the delineation of C. danicus, C. edwardsii, C. asymmetricus, and C. consuetus [48,70-73].

The NP4 Zone is comparable to the E. macellus Zone of [48], CP3 Zone of [43], and the interval equivalent to Subzone NTp5c to Zone NTp8 of [45]. The biostratigraphic significance of the LO of E. macellus as a zonal marker is doubtful as a consequence of its diachrony, being environmentally controlled, scarce abundance in the early stage of its range, being hard to recognize $[37,74]$, and absence in case of poor preservation and at high latitude areas [36,72-75]. As such, ref. [75] combined Zones NP3 and NP4 in case of poor preservation and at high latitude areas, whereas $[46,47]$ avoided using the appearance of E. macellus as a reliable bioevent. In this study, E. macellus is continuously recorded from the start of its stratigraphic range (Table S1) and is used as a guide for the definition of Zone NP4. Varol [45] subdivided the interval that correlates the Zone NP4 of [39] into three zones (NTp6, NTp7, and NTp8) and six subzones (NTp5c, NTp7a, NTp7b, NTp8a, NTp8b, and NTp8c). This zonation was followed by several authors [11-13,25,37,76]; however, this zonation cannot be completely applicable in this study. Moreover, the Zone NP4 of [39] was subdivided into Subzones NP4a and NP4b, relying on the LO of Sphenolithus primus [77,78]. Agnini et al. [46,47] gathered S. moriformis and S. primus in one group, S. moriformis group, and used its LO to delineate the base of Zone CNP6. However, several authors noted that $S$. primus appears in the fossil record with very rare and discontinuous occurrence $[18,37,79]$. Furthermore, intermediate forms between Sphenolithus and Octolithus were noted [74], which makes the delineation of the accurate LO of $S$. primus difficult. Moreover, the LO 
of $S$. primus was recorded at different levels $[19,37,80]$. Consequently, it was concluded that this bioevent might be an unreliable marker [81]. In contrast, the LCtO of S. primus has been considered a significant bioevent $[46,77]$. At Zumaia, S. primus first occurs $5.8 \mathrm{~m}$ below its lowest continuous occurrence [19] and below the D/S boundary [82]. In Tunisia, S. primus first occurs at about $8 \mathrm{~m}$ above the LDE [13]. At Qreiya in Egypt, S. primus occurs at about $2.5 \mathrm{~m}$ above the D/S boundary $[15,25,83]$. In the present study, S. primus appears with rare and inconsistent occurrence in the early stage of its stratigraphic range (Table S1). Moreover, S. primus appears above the LOs of Diantholitha mariposa, D. alata, D. magnolia, Lithoptychius felis, L. collaris, L. varolii, L. schmitzii, and L. chowii (Table S1).

The LO of F. tympaniformis was regarded as a reliable zonal marker by several authors $[38,42,44,47]$. The condensation of Zone NP5 indicates a hiatus in this interval, possibly resulted from irregular palaeotopography and/or tectonic activity. It was suggested to further subdivide the Zone NP5 depending on the successive appearances of Bomolithus elegans, then Heliolithus cantabriae [44]. Agnini et al. [46,47] used the first appearance of $H$. cantabriae as a zonal guide to the entry of the Zone CNP8; however; $H$. cantabriae is scarce in the early stage of its stratigraphic range, the exact level of its LO is inconsistent, and intermediate morphotype between species $H$. cantabriae and species $H$. kleinpellii were recorded $[44,74,82]$. Accordingly, the first appearance of $H$. cantabriae has to be utilized as a marker with caution. In this study, $H$. cantabriae is very rare (Table S1).

The Zone NP6 is comparable to the Zone NP6 of [39], the Heliolithus kleinpellii Zone of [48], Zone CP5 of [43], and Subzones NTp10b and NTp10c as well as Subzone NTp11a of [45]. The reliability of the LO of H. kleinpellii as a zonal marker was disputed [6], and thus, some authors suggested that it might be diachronous [84]. In contrast, it was not documented from several sections in Egypt $[78,85,86]$ as a result of a hiatus at the S/T transition.

The Zone NP7 / 8 is comparable to Zones CP6 plus CP7 of [43] and the interval between Subzones NTp11a and NTp16a of [45]. Discoaster mohleri has been considered a reliable zonal marker all over the world [39,45,47,48]. For taxonomic reasons, D. gemmeus Zone was changed to the D. mohleri Zone [87]. Heliolithus riedelii is absent in many sections [44], affected by taxonomic disputes [45], and its stratigraphic range is inconsistent [48,74]. Thus, it was considered unreliable marker for zonation [74], and Zones NP7 and NP8 [39] were combined by [48] in Discoaster mohleri Zone. Bukry [40] used D. nobilis as a zonal marker to delineate the base of the Zone NP8; however, the LO of D. nobilis was encountered in coincidence with the LO of D. multiradiatus, which makes it unreliable bioevent for biozonation [48]. Heliolithus riedelii have not been recorded in the Paleocene successions in Egypt [88]. Several authors noted that this zone is restricted to the Tarawan Fm. in several Paleocene outcrops in Egypt $[6,21,85]$.

\subsection{The Latest Danian Event}

Previous studies placed the D/S boundary in Egypt at the base of a distinct organic-rich shale bed $[30,31,36]$. Later investigations documented that this marker bed is older than the D/S boundary [11-13,15] and was referred to as the Latest Danian Event (LDE, [25]). Similar findings were noted in sections from different areas in the world [13,14,19,25,31,79,89]. Variations in lithology, carbon isotope values, and biotic assemblages support warming conditions during this interval $[10,90]$. However, the isotopic data in some Egyptian and Tunisian sections do not support this point of view $[13,24]$.

The base of the LDE at Zumaia is correlative to the contact between the Crowded Member and the Stratified Member of the Aitzgorri Fm., about $10 \mathrm{~m}$ below the base of Selandian [15]. The marker beds that associate the LDE are commonly associated with the appearance of calcareous nannofossil species, where Chiasmolithus edentulus is the most important bioevent marking of this event in the southern Tethyan area [79]. It represents a reliable bioevent for correlating the type locality of the Danian in Denmark, the GSSP in Spain, the North Sea, and the southern Tethys [19,70]. Agnini et al. [46] grouped C. edentulous, C. bidens, and C. solitus in the Chiasmolithus solitus group. The LO of C. edentulus 
occurs below the LDE and in coincidence with the LO of the small Lithoptychius. However, the LCtO of $S$. primus occurs after the LDE; therefore, the LDE can be traced within the interval between these two bioevents $[11,13,19,25]$. At the Zumaia section, C. edentulus occurs at $\sim 10 \mathrm{~m}$ below the top of Danian and in coincidence with the LOs of $L$. chowii and $L$. varolii [19]. However, at Qreiya and ODP Site 1262, the C. bidens group appears first [37]. In Tunisia, $C$. edentulus occurs within or just above the base of the LDE marker bed in coincidence with the first appearance of small Lithoptychius (e.g., L. felis, L. chowii, etc.) and the LCtO of Pontosphaera $[13,25]$. In this study, the LO of C. edentulus occurs in Sample 25 (5.3 $\mathrm{m}$ ) within the LDE bed in coincidence with LOs of Diantholitha magnolia and B. elegans and just above the LOs of D. alata, D. mariposa, L. varolii, L. felis, and L. collaris (Figure 3, Table S1).

The LO of genus Fasciculithus is a significant calcareous nannofossil bioevent in the Paleocene [37]. Based on the structure and morphology, fasciculiths species were grouped into four genera, namely Fasciculithus, Lithoptychius, Diantholitha, and Gomphiolithus [91]. At Zumaia, the early representatives of the fasciculiths group are G. magnus and G. magnicordis, which appear about $10.2 \mathrm{~m}$ below the base of Selandian [15]. These species were noted in the basal portion of Zone NP4, though they are scarce and had a short stratigraphic range $[37,48,91]$. They are not observed in this study. Diantholitha species were recorded below the first appearance of the representatives of Chiasmolithus bidens group at Zumaia in Spain, Walvis Ridge in South Atlantic, and Qreiya in Egypt [37]. Similar results are found in the present study (Table S1).

The fasciculiths group experienced different episodes of radiation $[6,18,19,24,37,74,79,91]$. The first radiative episode of fasciculiths at Zumaia was marked by the appearance of Fasciculithus spp. [19], which had been called Diantholitha mariposa by [91], who documented the beginning of this radiative episode just below the LO of C. edentulus. A similar record was noted in Tunisia in coincidence with the LDE distinct bed and slightly below the LDE marker layer in Egypt [19,22,25]. Thomsen and Heilmann-Clausen [17] delineated the first radiative episode of fasciculiths by the appearances of Lithoptychius varolii, L. chowii, and Diantholitha spp.; however, ref. [37] observed that Diantholitha spp. first appears below L. varolii and L. chowii. Furthermore, they introduced L. schmitzii as a new species occurring in the interval between the LOs of L. varolii and L. chowii. They suggested approximating the first radiative episode of Fasciculithus by this bioevent in case of the absence of L. varolii and L. chowii. Moreover, ref. [37] marked the first radiation of fasciculiths by the LOs Lithoptychius spp. that coincides with the base of the LDE.

In this study, the first representative of fasciculiths is Lithoptychius schmitzii, which appears in Sample $23(5.05 \mathrm{~m})$, just below the LDE distinct bed (Figure 3, Table S1). Moreover, the LO of L. schmitzii is coincident with the LOs of Pontosphaera exilis and Neococcolithes protenus and is followed by the diversification of fasciculiths, as reflected by the LOs of $D$. alata, D. mariposa, L. varolii, L. felis, and L. collaris in the base of the LDE bed (Sample 24) (Figure 3, Table S1). The diversity of calcareous nannofossil assemblages did not show any considerable change across the LDE; however, the abundance dropped from 656 specimens in Sample $23(5.05 \mathrm{~m})$ to 473 specimens in Sample $24(5.2 \mathrm{~m})$ and increased to 720 specimens in Sample 25 (5.3 m) (Figure 4, Table S1). 


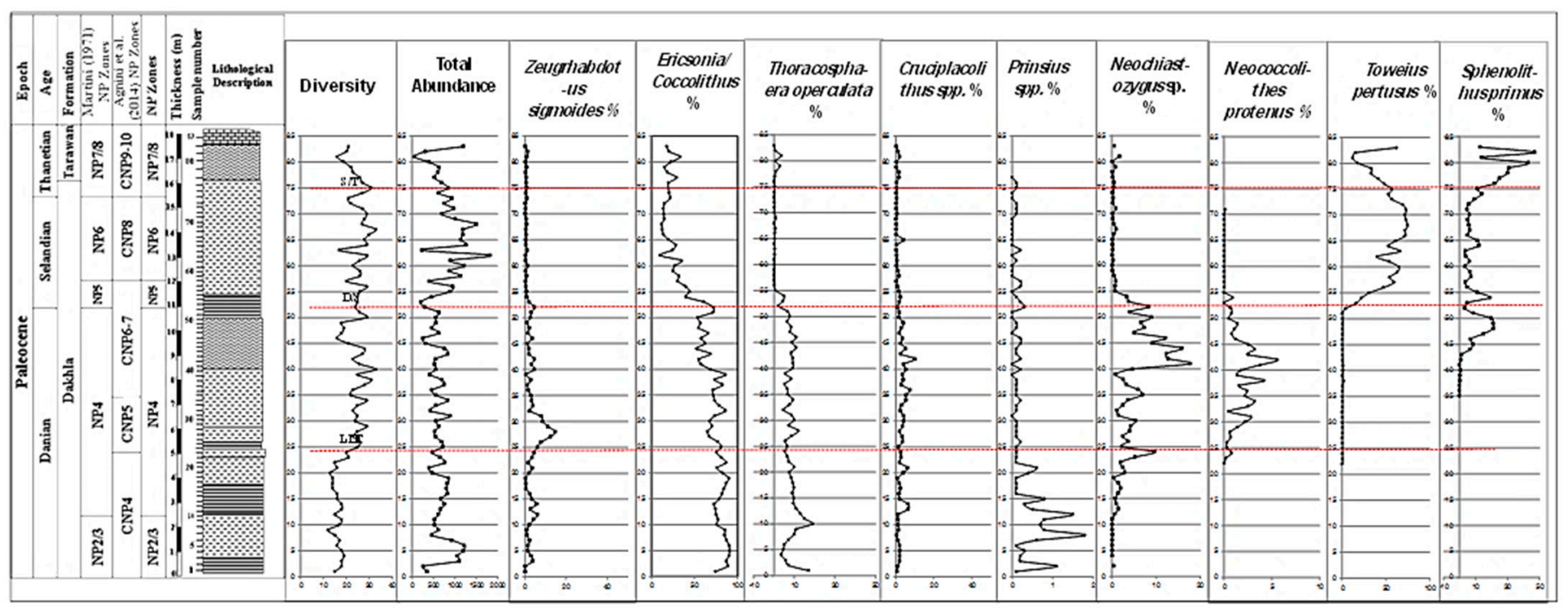

Figure 4. Calcareous nannofossil diversity, abundance, and significant taxa at Gebel Nezzazat section.

\subsection{The Danian/Selandian Boundary}

The definition of this boundary is generally problematic because of the rarity or absence of the marker species that are used as zonal markers for this interval [25]. In Denmark, ref. [89] placed the D/S boundary at the change from the uppermost Danian limestones to the lowermost Selandian Greensand in coincidence with the NP4/NP5 zonal boundary. At Zumaia, the ground of the Selandian was ratified within the topmost of Zone NP4 at the end of the last common occurrence of species Braarudosphaera bigelowii shortly above or in coincidence with the second radiation of fasciculiths and close to the ground of Zone NP5 [15]. The Acme End of B. bigelowii is a reliable bioevent in sections from the Northern Atlantic and adjacent areas [19,79]; however, it cannot be applied to section from the Tethyan area [6], and the present study supports this point of view (Table S1).

Relying on the variations in the calcareous nannofossil assemblage, the D/S boundary in the Egyptian sections was denoted at the beginning of Zone NP5 [92], at the first appearance of fasciculiths taxa [78,86], or at the first appearances of fasciculiths and Sphenolithus primus [93]. Sprong et al. [11] denoted the base of Subzone NTp8b of [45] at Qreiya based on the LOs of Lithoptychius billii and L. ulii at about $0.5 \mathrm{~m}$ on top of the LDE and placed the D/S transition in this interval. Aubry and Salem [26] identified the D/S boundary based on the LOs of Diantholitha and Lithoptychius and considered the first appearance of Diantholitha mariposa as the most significant bioevent for the NP4a/NP4b subzonal boundary, which is coincident with base of Selandian. Aubry and Salem [27] proposed the first occurrence and diversification of the Lithoptychius and Diantholitha to delineate the D/S boundary at Qreiya. The base of Selandian was also delineated within the Zone NP4 at the zonal boundary between planktonic foraminiferal Zones P2 and P3 [94] and at the top of a major negative carbon isotope excursion [95]. Furthermore, the second radiative episode of fasciculiths was considered as the primary marker to delineate the D/S boundary [15,37]. The LO of Lithoptychius ulii has been utilized to recognize the start of this radiation [19]. At Zumaia, L. ulii first occurs at about $0.20 \mathrm{~m}$ below the D/S boundary, whereas $F$. tympaniformis first occurs about $1.1 \mathrm{~m}$ above this boundary [15]. Consequently, the D/S boundary at the Tethyan sections can be approximated in between the LOs of L. ulii and F. tympaniformis [15].

At Gebel Nezzazat, the LO of L. ulii is recorded in Sample 50 (10.4 m) (Figure 3, Table S1), about $0.4 \mathrm{~m}$ below the base of Zone NP5 (10.9 m). In addition, the LOs of L. ulii, L. billii, L. stegostus, and L. janii are coincident, though the LO of L. ulii should be earlier [37]. The missing of subsequent appearances of these events indicates diachronic nature of the LOs of these taxa, a hiatus, or insufficient sampling resolution. In this study, the D/S boundary is identified in Sample $52(10.9 \mathrm{~m})$ at the top of Zone NP4 in coincidence with a distinct and sudden drop in the abundance of calcareous nannofossil assemblage from 
632 in Sample 51 to 302 and 207 specimens in Samples 52 and 53, respectively (Figure 4, Table S1), which might be associated to enhanced carbonate dissolution within this interval.

\subsection{The Selandian/Thanetian Boundary}

The Zumaia section in northern Spain was selected as the GSSP for the base of the Thanetian Stage that is defined as the base of magnetochron C26n [82]. No characteristic variations in lithology, biotic association, or carbon isotope values have been observed across the S/T transition at its GSSP [15]. Furthermore, the base of the Thanetian occurs at about $2.8 \mathrm{~m}$ from the MPBE that occurs below it. The MPBE bioevent has been documented in different areas worldwide $[8,11,90,96]$ and is considered as a significant criterion for the approximation of the base of the Thanetian Stage [15]. The MPBE at Zumaia occurs about $4.5 \mathrm{~m}$ above the base of calcareous nannofossil Zone NP6 that occurs about $6.5 \mathrm{~m}$ below the S/T boundary [15]. Accordingly, the base of Thanetian was approximated within the upper part of Zone NP6, about $2 \mathrm{~m}$ above the MPBE [15]. The considerable variations in the calcareous nannofossils associated with the S/T transition at Zumaia are the occurrence and radiation of Heliolithus, as well as the LO of Discoaster [15] and the LOs of several taxa, such as Toweius eminens, Bomolithus conicus, Coronocyclus nitescens, Sphenolithus anarrhopus, and Zygodiscus bramlettei [97].

The base of the Thanetian Stage in Egypt is commonly delineated by the LO of Discoaster mohleri [6,81]. Tantawy [85] approximated it at the top of a major negative carbon isotope anomaly within Zone NP6. The base of Thanetian in several sections in Egypt is placed in coincidence with the lithological change from Dakhla Fm. to Tarawan Fm., which indicates a hiatus at this boundary [6,9]. In this study, the S/T boundary is approximated at the base of Zone NP7 / 8 that extends from the uppermost Dakhla Fm. to the Tarawan Fm. (Figure 3). No remarkable changes in calcareous nannofossils are noted across this interval except the appearance of $D$. mohleri and continuous occurrence of $B$. megastypus as well as the increase in abundance of H. kleinpellii (Samples 71-73) (Figure 5, Table S1). Furthermore, no distinctive variation in the abundance of the calcareous nannofossil assemblages close to the NP6/NP7/ 8 zonal boundary were detected, except the sudden drop to 57 and 306 specimens in Samples 81 and 82, respectively (Figure 4, Table S1). This drop probably resulted from increased dissolution of carbonates. Also, it might be related to the ELPE/MPBE and/or the STTE of [8].

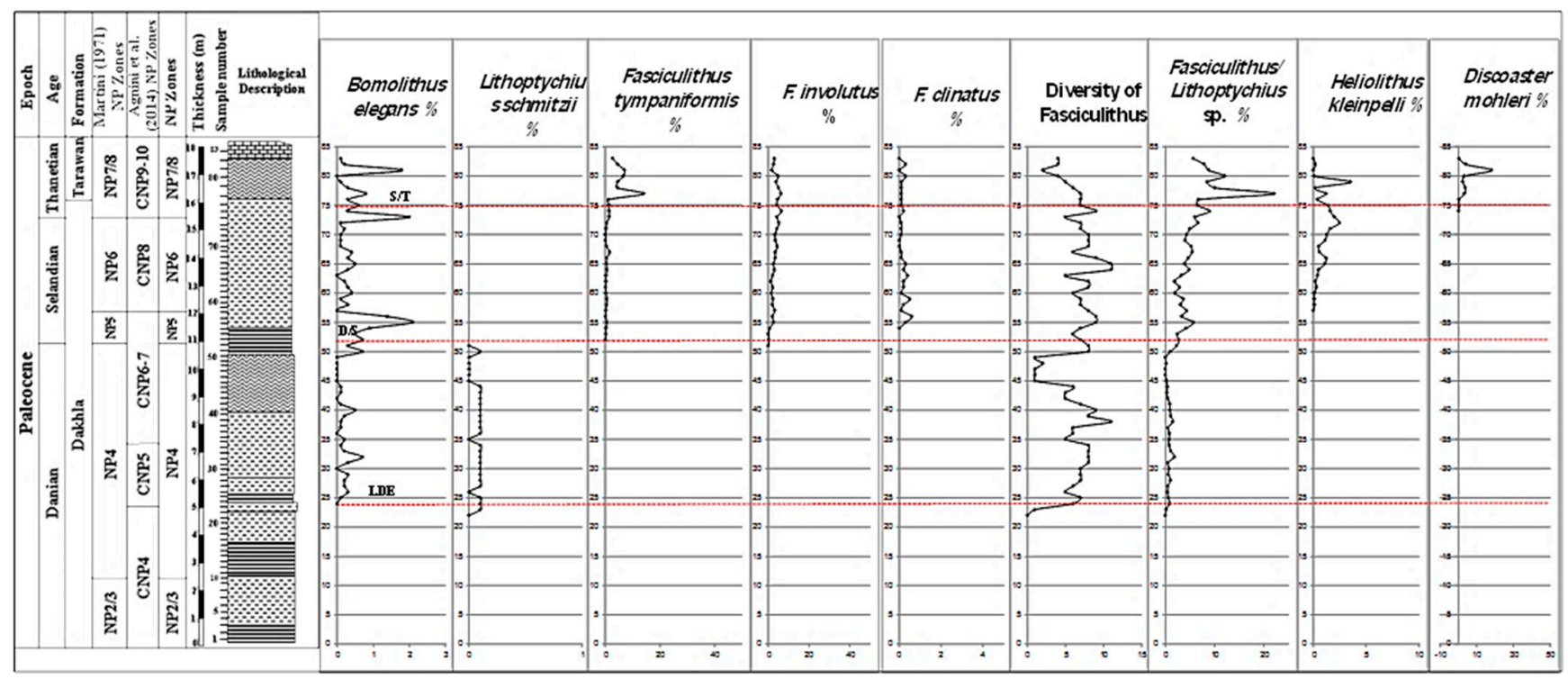

Figure 5. Plot of relative abundances of significant calcareous nannofossil taxa at Gebel Nezzazat section. 


\subsection{Paleoecology \\ 5.5.1. Danian Record}

The calcareous nannofossil assemblages of the studied section suggest relatively warmwater conditions prevailed during the Danian Stage, where the taxa that are considered as warm-water indicators dominate the assemblage. These conditions are punctuated by minor drops in temperatures, as indicated by minor increases in abundance of cold-water forms (Figure 6). Ericsonia subpertusa and Coccolithus pelagicus dominate the Paleocene calcareous nannofossil assemblages at Gebel Nezzazat section (Figure 4, Table S1). Most authors interpreted them as warm-water indicators [21,56,98-100] with a preference for oligotrophic conditions $[4,37,62,98,101,102]$; however, some authors considered C. pelagicus as eutrophic taxon [101]. Prinsius is commonly interpreted as eutrophic/cold-water indicator $[4,50,56,103-106]$. However, it is also considered as a mesotrophic form $[37,53,101,107]$. Monechi et al. [37] documented that genus Prinsius dominates calcareous nannofossil assemblages during Late Danian; however, this finding is not recorded in the present study (Figure 4, Table S1).

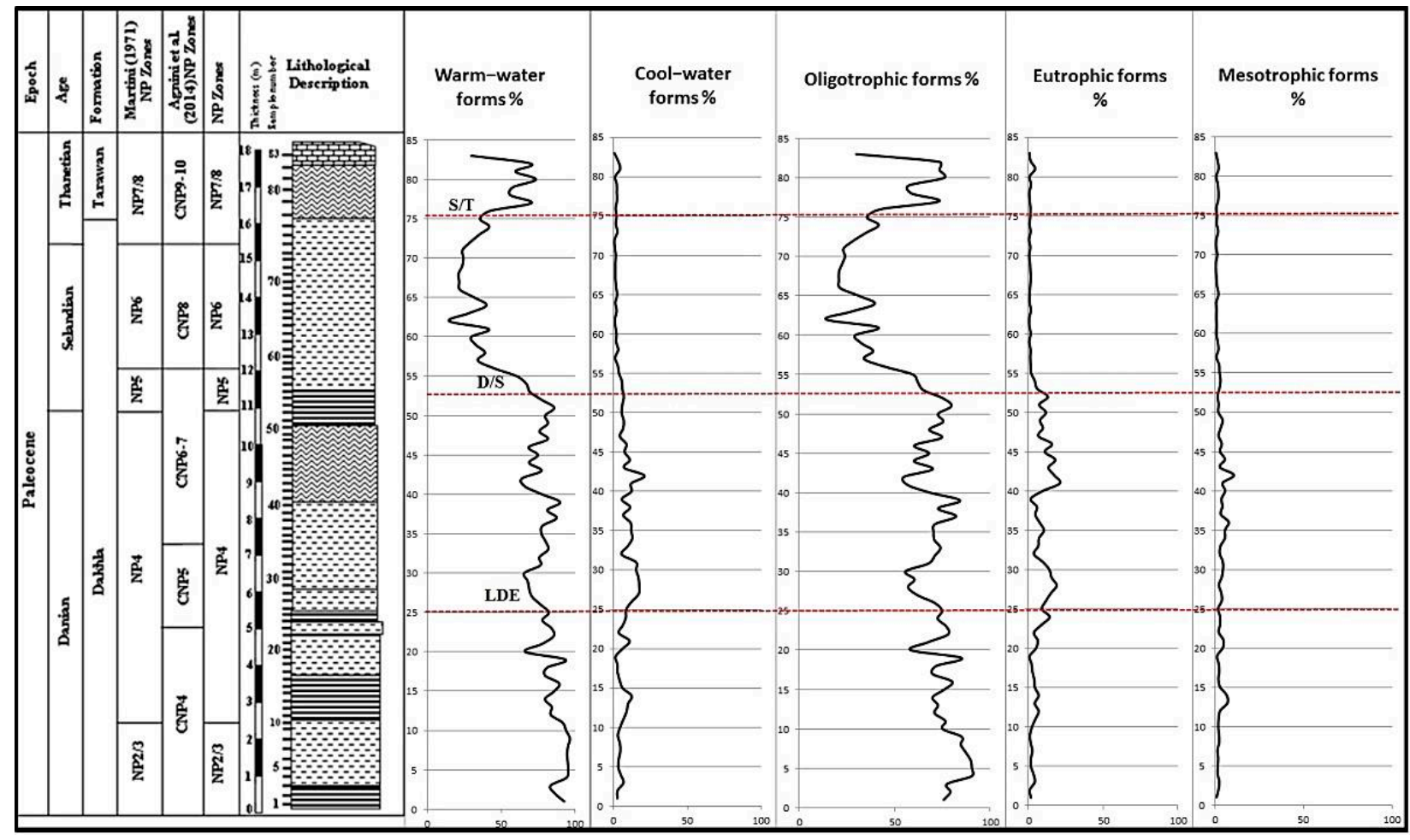

Figure 6. Changes in selected calcareous nannofossil ecological groups at Gebel Nezzazat section.

Zeugrhabdotus sigmoides can be considered as a cold-water indicator [36,103]; it is also considered as an indicator for eutrophic to mesotrophic and cold-water conditions by several authors [54,106]. At Gebel Nezzazat, Zeugrhabdotus sigmoides is rare in the lower part of the Danian interval (Samples 1 and 2) and varies upward till reaches a maximum abundance in Sample 28 (about $5.95 \mathrm{~m}$ ) slightly above the LDE distinct bed (Figure 4, Table S1). In addition, it shows a sudden drop in the basal Sample of the Selandian Stage (Table S1). No considerable change in its abundance is noted close the NP6/NP7 / 8 zonal boundary at the study section (Table S1).

Thoracosphaera operculata flourishes in several low- to middle-latitude areas [108-113]. Thoracosphaera is regarded as a species resistant to unusual climatic conditions and great variations in fertility [114]. At the study section, it occurs with common to abundant occurrences during the Danian, though it shows a slight decrease in Sample 24 in the base of the LDE distinct bed (Table S1). The abundance of T. operculata continued with 
common to abundant occurrences during the Danian and suddenly dropped in Sample 52 in coincidence with the D/S boundary (Figure 4, Table S1).

The genus Cruciplacolithus appears during the Danian Age. The representatives of this genus are rare to common at Gebel Nezzazat (Figure 4, Table S1). This genus is considered as a cool-water taxon [115], and it prefers mesotrophic conditions [53,101]. The abundance shows a slight drop in Samples 24 and $25(5.2-5.3 \mathrm{~m})$ in coincidence with the LDE interval and increases upward, then suddenly decreases in Samples 52 and 53 (10.9-11.1 m) in the basal portion of the Selandian interval (Table S1). It occurs with low abundances and without considerable variation during the Selandian-Thanetian interval (Table S1).

The genus Chiasmolithus is represented in the study sections by C. danicus, C. consuetus, C. edentulus, C. bidens, C. solitus, and C. grandis, and it is commonly interpreted as an indicator for cold-water conditions $[40,50,60,106]$ and is adapted to mesotrophic to eutrophic water $[50,63,98,101,107,115,116]$. However, ref. [53] found it to prefer oligotrophic conditions. The present study supports the former view, where it occurs sporadically with rare to common occurrence throughout the Danian-Thanetian interval at the study section (Table S1).

The genus Neochiastozygus is suggested as indicative of mesotrophic conditions [107]. Representatives of this genus in the study section are rare or few in the lower part of the Danian Stage, and their abundances increase upward to 5.3 and $9.6 \%$ from the total assemblage in Samples 23 and 24 (Figure 4, Table S1), respectively, and suddenly decrease to $2.2 \%$ in Sample 25 in coincidence with the top of the LDE distinct bed (Figure 4).

Sphenolithus is considered to be indicator of warm and oligotrophic environments based on its close association with Discoaster [50,53,56,101,117]. Gibbs et al. [63,118] concluded that the productivity is the main factor affecting the distribution and abundance of Sphenolithus. In this study, S. primus first occurs in the upper part of the Danian and increases in abundance in the uppermost of Zone NP4 slightly below the D/S boundary; it abruptly drops in Samples 52 and 53 in the basal part of the Selandian and increases upward without any remarkable variation during the Selandian-Thanetian interval (Figure 4, Table S1).

The ecological preference of Fasciculithus is hard to define [107]; however, it is regarded as a warm-water and oligotrophic indicator due to its accompany with Discoaster $[4,50,53,56,63,107,118]$. In contrast, some authors suggested a deep habitat for this taxon based on its large size and robust morphology $[53,119]$. This study supports warmwater and oligotrophic preference for this genus. Fasciculithus group appears just below the LDE distinct bed and increases in abundance and diversity upward, then fluctuates in abundance slightly below the top of Danian and increases upward (Figure 5, Table S1). The first radiation of this group is approximated in Sample 24 (about $5.2 \mathrm{~m}$; the LOs of Diantholitha mariposa, D. alata, L. varolii, L. felis, and L. collaris) in coincidence with the base of the LDE marker bed (Figure 5, Table S1), and the second radiative episode is approximated in Sample 50 (LOs of L. ulii, L. billii, L. stegostus, and L. janii; $10.4 \mathrm{~m}$ ) slightly below the D/S boundary (Figure 5; Table S1). No considerable variation in the abundance of Fasciculithus is noted throughout the Selandian-Thanetian interval (Figure 5, Table S1).

The lower part of the Danian interval (i.e., from the base up to Samples 22) is characterized by relatively lower level of diversity but high values of abundance. This interval is dominated by warm-water and oligotrophic calcareous nannofossils taxa. The upper part of the Danian is marked by a slight decrease of warm-water taxa associated with an increase in the eutrophic ones. On the basis of it, prevailing warm-water and oligotrophic conditions are inferred for the entire Danian record. The Danian-Selandian transition marks a significant decrease in warm-water and oligotrophic taxa.

\subsubsection{Selandian Record}

No marked variations in the calcareous nannofossils are noted in the Selandian (Figure 6, Table S1). A remarked slight decrease in the relative abundances of the warmwater indicator taxa from $85.9 \%$ in Sample 51 to $77.5 \%$ and $69.4 \%$ in Samples 52 and 53, 
respectively, in the basal part of the Selandian (Figure 6, Table S2) probably indicates that the D/S boundary was preceded by slight increase and followed by slight decrease in the temperature and oligotrophic conditions as well. Similar drops are noted in the relative abundances of the cool-water indicators as well as oligotrophic, eutrophic, and mesotrophic taxa (Figure 6, Table S2). These indicate that these sudden decreases often resulted from an increase in dissolution of carbonates rather than changes in the temperature and/or fertility. In addition, a sudden drop in the relative abundances of calcareous nannofossils was recorded in Sample 62 (about 12.8 m, Figure 6).

Toweius pertusus shows abundant occurrences during the Selandian and reaches maximum abundance in Sample 68 (75\% from the total assemblage) within Zone NP6 (Table S1). This species is inferred to have a wide toleration for fertility and temperature [53]. Moreover, Sphenolithus and Heliolithus show common occurrences during the Late Selandian (Table S1). Heliolithus is regarded as a warm-water indicator and prefers more oligotrophic conditions $[4,50]$.

The affinity of calcareous nannofossil taxa still suggest prevailing warm and oligotrophic conditions during the Selandian Stage at Gebel Nezzazat but not dominant as during the Danian record. The Selandian-Thanetian transition shows a significant increase of warm and oligotrophic conditions.

\subsubsection{Thanetian Record}

The calcareous nannofossil assemblages of the Thanetian sequence in the study section are dominated by C. pelagicus, E. subpertusa, E. robusta, T. pertusus, S. primus, F. tympaniformis, H. kleinpellii, F. involutus, and D. mohleri (Table S1). Discoaster is considered to be adapted to warmer water conditions [40,50,60,107] and oligotrophic environmental conditions [50,98,101,102]. Thus, warm-water and oligotrophic conditions can be inferred during the Thanetian Stage at the study section, as illustrated by their relative abundances from Samples 75-83 (Figure 6, Table S2). A remarked sudden drop of the calcareous nannofossils is detected in Sample 81 (17.2 m) within Zone NP7/8 (Figure 4, Table S1), and it can be ascribed to an increased dissolution of carbonates rather than changes in temperature and/or fertility. This conclusion is evident by the sudden decrease in various calcareous nannofossil groups regardless their latitudinal and paleofertility preferences (Tables S1 and S2).

\section{Conclusions}

The variations in lithology, calcareous nannofossil assemblages, and paleoenvironmental conditions are investigated in the Paleocene record at Gebel Nezzazat (central Sinai, Egypt). The Paleocene studied interval covers $16 \mathrm{~m}$ and $2 \mathrm{~m}$ from the Dakhla and Tarawan Fms., respectively. A distinct bed of about $30 \mathrm{~cm}$ thick dark gray organic-rich calcareous shale within the Dakhla Fm. marks the LDE. Five calcareous nannofossil zones are delineated including combined Zone NP2/3, Zones NP4, NP5, and NP6 as well as combined Zone NP7/8. The biostratigraphic significance of the Paleocene calcareous nannofossil bioevents are discussed in this study. Lithoptychius schmitzii is the first representative of fasciculiths and appears just below the LDE marker bed in coincidence with the LOs of Pontosphaera exilis and Neococcolithes protenus. It is directly followed by the first radiative episode that is marked by the LOs of Diantholitha mariposa, D. alata, L. varolii, L. felis, and L. collaris in coincidence with the base of the LDE bed. The abundance of calcareous nannofossil assemblages shows remarkable drop in the basal part of the LDE bed. The Danian/Selandian (D/S) boundary is approximated at the base of Zone NP5. It is accompanied with a distinct and sudden drop in the abundance of calcareous nannofossil assemblage, which indicates an increase in the dissolution of carbonates across this boundary. The LO of L. ulii co-occurs with the Los of L. billii, L. stegostus, and L. janii. The absence of the subsequent occurrences of these bioevents indicates insufficient sampling resolution, inconsistent Los of these taxa, and/or a hiatus in this interval. The Selandian/Thanetian $(\mathrm{S} / \mathrm{T})$ boundary is detected at the base of Zone NP7/8 that extends from the uppermost 
Dakhla Fm. to the Tarawan Fm. and supports a conformable relationship between these two formations at the studied section. Calcareous nannofossil assemblages do not show considerable changes through the Selandian-Thanetian transition except the LO of Discoaster mohleri, the LctO Bomolithus megastypus, and the increase in abundance of Heliolithus kleinpellii. In addition, a distinctive drop in abundance is recorded within Zone NP7/8, likely resulting from marked carbonate dissolution. The changes of ecological groups of calcareous nannofossils are used for tracking the Paleocene climatic variations at Gebel Nezzazat. On the basis of it, prevailing of warm and oligotrophic conditions is inferred along the studied Paleocene record, particularly along the Danian Stage. A remarked decrease in warm and oligotrophic conditions can be delineated at the Danian-Selandian transition, which culminated along the Selandian Stage. An increase of warm and oligotrophic conditions is recovered during the Selandian-Thanetian transition and the recorded Thanetian Stage of the present study. The noticeable decrease in calcareous nannofossils abundances along the Selandian and Thanetian Stages can be attributed to an increase in carbonate dissolution rather than variations in the paleotemperature and/or paleofertility.

Supplementary Materials: The following supporting information can be downloaded at: https: / / www.mdpi.com/article/10.3390/geosciences12020096/s1, Table S1: Abundance, diversity, and quantitative distribution of the different calcareous nannofossil taxa represent the Danian-Thanetian at G. Nezzazat (Central Sinai, Egypt); Table S2: The relative abundances (\%) of the different calcareous nannofossil ecological groups at G. Nezzazat.

Author Contributions: Conceptualization, A.M.K., M.F., T.A.A. and A.S.Z.; Data curation, A.M.K., T.A.A. and A.S.Z.; Formal analysis, A.M.K., M.F., T.A.A. and A.S.Z.; Methodology, A.M.K., M.F., T.A.A. and A.S.Z.; Supervision, A.M.K., M.F., L.J., F.F. and A.S.Z.; Validation, A.M.K., M.F., L.J., T.A.A., F.F. and A.S.Z.; Visualization, A.M.K., T.A.A. and A.S.Z.; Writing-original draft, A.M.K. and T.A.A.; Writing-review and editing, A.M.K., M.F., L.J., T.A.A., F.F. and A.S.Z. All authors have read and agreed to the published version of the manuscript.

Funding: This research received no external funding.

Institutional Review Board Statement: Not applicable.

Informed Consent Statement: Not applicable.

Data Availability Statement: Data supporting this paper are available in Tables S1 and S2 in the Supplementary Materials.

Acknowledgments: The first author expresses his deepest appreciation and gratitude to Sherwood Wise (Florida State University, USA) for helping in the investigation of this section. The authors are greatly indebted to the three anonymous reviewers and the Editor-in-Chief of Geosciences (MDPI) for their insightful suggestions and motivations during the reviewing and publication of this manuscript. L.J. is supported by Fundação de Amparo a Pesquisa do Estado de São Paulo (FAPESP) projects 2016/24946-9. The last author would like to extend his sincere thanks to the Institute of Geological Sciences and Oeschger Centre for Climate Change Research (University of Bern, Switzerland) for their support.

Conflicts of Interest: The authors declare no conflict of interest.

\section{References}

1. Jenkins, D.G.; Luterbacber, H.P. Paleogene Stages and their boundaries. Neues Jahrb. Geol. Paläontologie 1992, 186, 1-5.

2. Speijer, R.P.; Pälike, H.; Hollis, C.J.; Hooker, J.J.; Ogg, J.G. The Paleogene Period. In Geologic Time Scale 2020; Elsevier: Amsterdam, The Netherlands, 2021; Volume 2, pp. 1087-1140.

3. Bralower, T.J.; Premoli Silva, I.; Malone, M.J. New evidence for abrupt climate change in the Cretaceous and Paleogene: An ocean drilling program expedition to Shatsky Rise, northwest Pacific. GSA Today 2002, 12, 4-10. [CrossRef]

4. Bernaola, G.; Baceta, J.I.; Orue-Extebarria, X.; Alegret, L.; Martin-Rubio, M.; Arostegui, J.; Dinarès-Turell, J. Evidence of an abrupt environmental disruption during the mid-Paleocene biotic event (Zumaia section, western Pyrenees). Geol. Soc. Am. Bull. 2007, 119, 785-795. [CrossRef] 
5. Frontalini, F.; Coccioni, R.; Catanzariti, R.; Jovane, L.; Savian, J.F.; Sprovieri, M. The Eocene Thermal Maximum 3: Reading the environmental perturbations at Gubbio (Italy). In The Stratigraphic Record of Gubbio: Integrated Stratigraphy of the Late CretaceousPaleogene Umbria-Marche Pelagic Basin; Geological Society of America: Boulder, CO, USA, 2016; Volume 524, pp. 161-326.

6. Kasem, A.M.; Wise, S., Jr.; Faris, M.; Farouk, S.; Zahran, E. Calcareous nannofossil biostratigraphy of the Paleocene at the Misheiti section, East Central Sinai, Egypt. Arab. J. Geosci. 2017, 10, 455. [CrossRef]

7. Faris, M.; Obaidalla, N.A.; Metwally, A.A.; Salman, A.M.; Zaky, A.S. Late Cretaceous-Early Paleogene tectonic events at Farafra-Abu Minqar Stretch, Western Desert, Egypt: Results from calcareous plankton. Arab. J. Geosci. 2018, 11, 1-18.

8. Coccioni, R.; Frontalini, F.; Catanzariti, R.; Jovane, L.; Rodelli, D.; Rodrigues, I.M.; Savian, J.F.; Giorgioni, M.; Galbrun, B. Paleoenvironmental signature of the selandian-thanetian transition event (STTE) and early late paleocene event (ELPE) in the Contessa Road section (western Neo-Tethys). Palaeogeogr. Palaeoclimatol. Palaeoecol. 2019, 523, 62-77. [CrossRef]

9. $\quad$ Farouk, S.; Khalifa, M.A.; Hassan, M.M.A.; Papazzoni, C.A.; Frontalini, F.; Coccioni, R.; Zaky, A. Upper Paleocene to lower Eocene microfacies, biostratigraphy, and paleoenvironmental reconstruction in the northern Farafra Oasis, Western Desert (Egypt). Micropaleontology 2019, 65, 361-406.

10. Bornemann, A.; Schulte, P.; Sprong, J.; Steurbaut, E.; Youssef, M.; Speijer, R.P. Latest Danian carbon isotope anomaly and associated environmental change in the southern Tethys (Nile Basin, Egypt). J. Geol. Soc. 2009, 166, 1135-1142. [CrossRef]

11. Sprong, J.; Youssef, M.; Bornemann, A.; Schulte, P.; Stassen, P.; Steurbaut, E.; Kouwenhovens, T.J.; Speijer, R.P. A multi-proxy record of the Latest Danian Event at Gebel Qreiya, Eastern Desert, Egypt. J. Micropalaeontol. 2011, 30, 167-182. [CrossRef]

12. Sprong, J.; Kouwenhoven, T.J.; Bornemann, A.; Schulte, P.; Stassen, P.; Steurbaut, E.; Youssef, M.; Speijer, R.P. Characterization of the Latest Danian Event by means of benthic foraminiferal assemblages along a depth transect at the southern Tethyan margin (Nile Basin, Egypt). Mar. Micropaleontol. 2012, 86-87, 15-31. [CrossRef]

13. Sprong, J.; Kouwenhovens, T.J.; Bornemann, A.; Dupuis, C.; Speijer, R.P.; Stassen, P.; Steurbaut, E. In search of the Latest Danian Event in a paleobathymetric transect off Kasserine Island, north-central Tunisia. Palaeogeogr. Palaeoclimatol. Palaeoecol. 2013, 379-380, 1-16. [CrossRef]

14. Arenillas, I.; Molina, E.; Ortiz, S.; Schmitz, B. Foraminiferal and $813 \mathrm{C}$ isotopic event-stratigraphy across the Danian-Selandian transition at Zumaya (northern Spain): Chronostratigraphic implications. Terra Nova 2008, 20, 38-44. [CrossRef]

15. Schmitz, B.; Pujalte, V.; Molina, E.; Monechi, S.; Orue-Etxebarria, X.; Speijer, R.P.; Alegret, L.; Apellaniz, E.; Arenillas, I.; Aubry, M.-P.; et al. The Global Stratotype Sections and Points for the bases of the Selandian (Middle Paleocene) and Thanetian (Upper Paleocene) stages at Zumaia, Spain. Epis. Int. Geosci. Newsmag. 2011, 34, 220-243. [CrossRef]

16. Palcu, D.V.; Muraszko, J.R.; Jaqueto, P.F.; Jovane, L. The Birth of a Connected South Atlantic Ocean: A Magnetostratigraphic Perspective. Front. Earth Sci. 2020, 8, 375. [CrossRef]

17. Thomsen, E.; Heilmann-Clausen, C. The Danian-Selandian boundary at Svejstrup with remarks on the biostratigraphy of the boundary in western Denmark. B Geol. Soc. Den. 1985, 33, 341-362. [CrossRef]

18. Steurbaut, E.; Sztrákos, K. Danian/Selandian boundary criteria and North Sea basin-Tethys correlation based on calcareous nannofossil and foraminiferal trends in SW France. Mar. Micropaleontol. 2008, 67, 1-29. [CrossRef]

19. Bernaola, G.; Martín-Rubio, M.; Baceta, J.I. New high resolution calcareous nannofossil analysis across the Danian/Selandian transition at the Zumaia section: Comparison with South Tethys and Danish sections. Geol. Acta 2009, 7, 79-92.

20. Renevier, E. Tableau des terrains sédimentaires formés pendant les époques de la phase organique du globe Terrestre. Bulletin de la Société Vaudoise des Sciences Naturelles 1873, 12, 218-252.

21. Dupuis, C.; Aubry, M.-P.; Steurbaut, E.; Berggren, W.A.; Ouda, K.; Magioncalda, R.; Cramer, B.S.; Kent, D.V.; Speijer, R.P.; Heilmann-Clausen, C. The Dababiya Quarry section: Lithostratigraphy, clay mineralogy, geochemistry and paleontology. Micropaleontology 2003, 49, 41-59. [CrossRef]

22. Guasti, E.; Speijer, R.P.; Brinkhuis, H.; Smit, J.; Steurbaut, E. Paleoenvironmental change at the Danian-Selandian transition in Tunisia; Foraminifera, organic-walled dinoflagellate cyst and calcareous nannofossil records. Mar. Micropaleontol. 2006, 59, 210-229. [CrossRef]

23. Aubry, M.-P.; Ouda, K.; Dupuis, C.; Berggren, W.A.; Van Couvering, J.A.; Members of the Working Group on the Paleocene/Eocene Boundary. The Global Standard Stratotype-Section and Point (GSSP) for the base of the Eocene Series in the Dababiya section (Egypt). Episodes 2007, 30, 271-286. [CrossRef] [PubMed]

24. Aubry, M.-P.; Rodriguez, O.; Bord, D.; Godfrey, L.; Schmitz, B.; Knox, R. The First Radiation of the Fasciculiths: Morphologic adaptations of the coccolithophores to oligotrophy. Austrian J. Earth Sc. 2012, 105, 29-38.

25. Sprong, J.; Speijer, R.P.; Steurbaut, E. Biostratigraphy of the Danian/Selandian transition in the southern Tethys. Special reference to the lowest occurrence of planktic foraminifera Igorina albeari. Geol. Acta 2009, 7, 63-77.

26. Aubry, M.-P.; Salem, R. The Dababiya Quarry Core: Coccolith Biostratigraphy. Stratigraphy 2013, 9, $241-259$.

27. Aubry, M.-P.; Salem, R. The Dababiya Core: A window into Paleocene to Early Eocene depositional history in Egypt based on coccolith stratigraphy. Stratigraphy 2013, 9, 287-346.

28. Said, R. Planktonic foraminifera from the Thebes Formation, Luxor, Egypt. Micropaleontology 1960, 6, 277-286. [CrossRef]

29. Awad, G.H.; Ghobrial, M.G. Zonal stratigraphy of the Kharga Oasis. Ann. Geol. Surv. Egypt 1966, 34, 1-77.

30. Speijer, R. Danian-Selandian Sea-Level Change and Biotic Excursion on the Southern Tethyan Margin (Egypt); Special Paper 369; Geological Society of America: Boulder, CO, USA, 2003; pp. 275-290. 
31. Guasti, E.; Speijer, R.P.; Fornaciari, E.; Schmitz, B.; Kroon, D.; Gharaibeh, A. Transient Biotic Change within the Danian-Selandian Transition in Egypt and Jordan. Early Paleogene Environmental Turnover in the Southern Tethys as Recorded by Foraminiferal and Organic-Walled Dinoflagellate Cysts Assemblages. Ph.D. Thesis, University of Bremen, Bremen, Germany, 2005; pp. 75-110.

32. Soliman, M.F.; Obaidalla, N.A. Danian-Selandian transition at the Gabal el-Qreiya section, Nile Valley (Egypt): Lithostratigraphy, biostratigraphy, mineralogy and geochemistry. Neues Jahrb. Geol. Paläontologie 2010, 258, 1-30. [CrossRef]

33. Soliman, M.F.; Obaidalla, N.A.; Ahmed, E.A.; Kurzweil, J. Mid-Paleocene event at Gabal Nezzazat, Sinai, Egypt: Planktonic foraminiferal biostratigraphy, mineralogy and geochemistry. Arab. J. Geosci. 2014, 7, 4079-4099. [CrossRef]

34. Speijer, R.P. The late Paleocene event and a potential precursor compared: First results from Egypt. GFF 2000, $122,150-151$. [CrossRef]

35. Speijer, R.P. Systematics and paleoecology of the foraminifer Neoeponides duwi (Nakkady) from the Paleocene of Egypt. Micropaleontology 2003, 49, 146-150. [CrossRef]

36. Obaidalla, N.A.; El-Dawy, M.H.; Kassab, A.S. Biostratigraphy and paleoenvironment of the Danian/Selandian (D/S) transition in the Southern Tethys: A case study from north Eastern Desert, Egypt. J. Afr. Earth Sci. 2009, 53, 1-15. [CrossRef]

37. Monechi, S.; Reale, V.; Bernaola, G.; Balestra, B. The Danian/Selandian boundary at Site 1262 (South Atlantic) and in the Tethyan region: Biomagnetostratigraphy, evolutionary trends in fasciculiths and environmental effects of the Latest Danian Event. Mar. Micropaleontol. 2013, 98, 28-40. [CrossRef]

38. Gardin, S.; Monechi, S. Palaeoecological change in middle to low latitude calcareous nannoplankton at the Cretaceous/Tertiary boundary. Br. Soc. Geol Fr. 1998, 169, 709-723.

39. Martini, E. Standard Tertiary and Quaternary calcareous nannoplankton zonation. in Proc. II Planktonic Conference, Roma 1970, Roma. Tecnoscienza 1971, 2, 739-785.

40. Bukry, D. Low latitude coccolith biostratigraphic zonation. Initial Rep. DSDP 1973, 15, 685-703.

41. Bukry, D. Coccolith and silicoflagellate stratigraphy, northwestern Pacific Ocean, Deep Sea Drilling Project Leg 32. Init. Repts. DSDP 1975, 32, 677-701.

42. Sissingh, W. Biostratigraphy of Cretaceous calcareous nannoplankton. Geologie en Mijnbouw 1977, 56, 37-65.

43. Okada, H. Supplementary modification and introduction of code numbers to the low-latitude coccolith biostratigraphy (Bukry, 1973; 1975). Mar. Micropaleontol. 1980, 5, 321-325. [CrossRef]

44. Perch-Nielsen, K. Cenozoic calcareous nannofossils. In Plankton Stratigraphy; Bolli, H.M., Saunders, J.B., Perch-Nielsen, K., Eds.; Cambridge University Press: Cambridge, UK, 1985; pp. 427-554.

45. Varol, O. Palaeocene calcareous nannofossil biostratigraphy. In Nannofossils and Their Applications; Crux, J.A., Van Heck, S.E., Eds.; British Micropaleontological Society: Chichester, UK, 1989; Volume 12, pp. 267-310.

46. Agnini, C.; Fornaciari, E.; Raffi, I.; Catanzariti, R.; Pälike, H.; Backman, J.; Rio, D. Biozonation and biochronology of Paleogene calcareous nannofossils from low and middle latitudes. Newsl. Stratigr. 2014, 47, 131-181. [CrossRef]

47. Agnini, C.; Monechi, S.; Raffi, I. Calcareous nannofossil biostratigraphy: Historical background and application in Cenozoic chronostratigraphy. Lethaia 2017, 50, 447-463. [CrossRef]

48. Romein, A.J.T. Lineages in early Paleogene calcareous nannoplankton. Utrecht Micropaleontol. Bull. 1979, 22, 18-22.

49. Winter, A.; Jordan, R.W.; Roth, P.H. Biogeography of living coccolithophores in ocean waters. In Coccolithophores; Winter, A., Siesser, W.G., Eds.; Cambridge University Press: Cambridge, UK, 1994; pp. 161-178.

50. Bralower, T.J. Evidence of surface water oligotrophy during the Paleocene-Eocene thermal maximum: Nannofossil assemblage data from ocean drilling program Site 690, Maud rise, Weddell Sea. Paleoceanography 2002, 17, 13-1-13-12. [CrossRef]

51. Bornemann, A. Case Studies of Mesozoic Calcareous Nannofossils: Implications for Paleoecology, Calcareous Nannofossil Morphology and Carbonate Accumulation. Ph.D. Thesis, Ruhr-University, Bochum, Germany, 2003; 126p.

52. Watkins, D.K. Nannoplankton productivity fluctuations and rhythmically-bedded pelagic carbonates of the Greenhorn Limestone (Upper Cretaceous). Palaeogeogr. Palaeoclimatol. Palaeoecol. 1989, 74, 75-86. [CrossRef]

53. Fuqua, L.; Bralower, T.; Arthur, M.; Patzkowsky, M. Evolution of calcareous nannoplankton and recovery of marine food webs after the Cretaceous-Paleocene mass extinction. Palaios 2008, 23, 185-194. [CrossRef]

54. Okada, H.; Honjo, S. The distribution of oceanic coccolithophorids in the Pacific. Deep Sea Res. Oceanogr. Abstr. 1973, 20, 355-374. [CrossRef]

55. Thibault, N.; Gardin, S. The late Maastrichtian nannofossil record of climate change in the South Atlantic DSDP Hole 525A. Mar. Micropaleontol. 2007, 65, 163-184. [CrossRef]

56. Haq, B.U.; Lohmann, G.P. Early Cenozoic calcareous nannoplankton biogeography of the Atlantic Ocean. Mar. Micropaleontol. 1976, 1, 119-194. [CrossRef]

57. Bramlette, M.N.; Martini, E. The great change in calcareous nannoplankton fossils between the Maestrichtian and Danian. Micropaleontology 1964, 10, 291-322. [CrossRef]

58. Gartner, S. Calcareous nannofossils from the JOIDES Blake Plateau cores and revision of Paleogene nannofossil zonation. Tulane Stud. Geol. Paleontol. 1971, 8, 101-121.

59. Okada, H.; McIntyre, A. Seasonal distribution of modern coccolithophores in the western North Atlantic Ocean. Mar. Biol. 1979, 54, 319-328. [CrossRef]

60. Wei, W.; Wise, S.W., Jr. Biogeographic gradients of middle Eocene-Oligocene calcareous nannoplankton in the South Atlantic Ocean. Palaeogeogr. Palaeoclimatol. Palaeoecol. 1990, 79, 29-61. [CrossRef] 
61. Fisher, C.G.; Hay, W.W. Calcareous Nannofossils as Indicators of Mid-Cretaceous Paleofertility along an Ocean Front, US Western Interior; Special Paper 332; Geological Society of America: Boulder, CO, USA, 1999; pp. 161-180.

62. Tremolada, F.; Bralower, T.J. Nannofossil assemblage fluctuations during the Paleocene-Eocene thermal maximum at Sites 213 (Indian Ocean) and 401 (North Atlantic Ocean): Palaeoceanographic implications. Mar. Micropaleontol. 2004, 52, 107-116. [CrossRef]

63. Gibbs, S.J.; Bown, P.R.; Bralower, T.J. Ocean acidification and calcareous nannoplankton at the Paleocene-Eocene Thermal Maximum. Clim. Biota Early Paleogene 2006, 51.

64. Bernaola, G.; Monechi, S. Calcareous nannofossil extinction and survivorship across the Cretaceous-Paleogene boundary at Walvis Ridge (ODP Hole 1262C, South Atlantic Ocean). Palaeogeogr. Palaeoclimatol. Palaeoecol. 2007, 255, 132-156. [CrossRef]

65. Raffi, I.; Backman, J.; Zachos, J.C.; Sluijs, A. The response of calcareous nannofossil assemblages to the Paleocene Eocene Thermal Maximum at the Walvis Ridge in the South Atlantic. Mar. Micropaleontol. 2009, 70, 201-212. [CrossRef]

66. Hay, W.W.; Mohler, H.P. Calcareous nannoplankton from early Tertiary rocks at Pont Labau, France, and Paleocene-early Eocene correlations. J. Paleontol. 1967, 41, 1505-1541.

67. Hay, W.W.; Mohler, H.P.; Roth, P.H.; Schmidt, R.R.; Boudreaux, J.E. Calcareous nannoplankton zonation of the Cenozoic of the Gulf Coast and Caribbean-Antillean area and transoceanic correlation. Gulf Coast Assoc. Geol. Soc. J. 1967, 17, 428-480.

68. Hay, W.W. Utilisation stratigraphique des Discoasterides pour la zonation du Paleocene et de L'Eocene inferieur. Memoire Bur. Rech. Geol. Minières 1964, 28, 885-889.

69. Stradner, H. Vorkommen von Nannofossilien im Mesozoikum und Alttertiär. Erdöl-Zeitschrift für Bohr-und Fördertechnik 1961, 77, 77-88.

70. Van Heck, S.E.; Prins, B. A refined nannoplankton zonation for the Danian of the Central North Sea. Abhandlungen der Geologischen Bundesanstalt 1987, 39, 285-303.

71. Brotzen, F. On Tylocidaris species (Echinoidea) and the stratigraphy of the Danian of Sweden: With a bibliography of the Danian and Paleocene. In Sveriges Geologiska Undersokning, Arsbok; Norstedt \& Söner: Stockholm, Sweden, 1959; Volume 54, pp. 1-81.

72. Monechi, S.; Bleil, U.; Backman, J. Magnetobiochronology of Late Cretaceous-Paleogene and Late Cenozoic pelagic sedimentary sequences from the Northwest Pacific (Deep Sea drilling Project). In Initial Reports of the Deep Sea Drilling Project Leg, 86U.S.; Heath, G.R., Burckle, L.H., Eds.; Government Printing Office: Washington, DC, USA, 1985; pp. 787-797.

73. Fornaciari, E.; Giusberti, L.; Luciani, V.; Tateo, F.; Agnini, C.; Backman, J.; Oddone, M.; Rio, D. An expanded Cretaceous-Tertiary transition in a pelagic setting of the Southern Alps (central-western Tethys). Palaeogeogr. Palaeoclimatol. Palaeoecol. 2007, 255, 98-131. [CrossRef]

74. Agnini, C.; Fornaciari, E.; Raffi, I.; Rio, D.; Röhl, U.; Westerhold, T. High-resolution nannofossil biochronology of middle Paleocene to early Eocene at ODP Site 1262: Implications for calcareous nannoplankton evolution. Mar. Micropaleontol. 2007, 64, 215-248. [CrossRef]

75. Martini, E. Cretaceous to Recent Calcareous Nannoplankton from the Central Pacific Ocean (DSDP Leg 33). Initial. Rep. DSDP 1976, 33, 383-423.

76. Steurbaut, E.; Dupuis, C.; Arenillas, I.; Molina, E.; Matmati, M.F. The Kalaat Senan section in central Tunisia: A potential reference section for the Danian/Selandian boundary. GFF 2000, 122, 158-160. [CrossRef]

77. Quillévéré, F.; Aubry, M.-P.; Norris, R.D.; Berggren, W.A. Paleocene oceanography of the eastern subtropical Indian Ocean: An integrated magnetobiostratigraphic and stable isotope study of ODP Hole 761B (Wombat Plateau). Palaeogeogr. Palaeoclimatol. Palaeoecol. 2002, 184, 371-405. [CrossRef]

78. Faris, M.; Salem, R. Paleocene-Eocene calcareous nannofossil biostratigraphy in west central Sinai, Egypt. In Proceedings of the 8th Conference on Geology of Sinai for Development, Ismailia, Egypt, 3 December 2007; pp. 1-14.

79. Dinarès-Turell, J.; Stoykova, K.; Baceta, J.I.; Ivanov, M.; Pujalte, V. High-resolution intra- and interbasinal correlation of the Danian-Selandian transition (Early Paleocene): The Bjala section (Bulgaria) and the Selandian GSSP at Zumaia (Spain). Palaeogeogr. Palaeoclimatol. Palaeoecol. 2010, 297, 511-533. [CrossRef]

80. Arney, J.; Wise, S.W. Paleocene-Eocene Nannofossil Biostratigraphy of ODP Leg 183, Kerguelen Plateau. In Proceedings of the Ocean Drilling Program, Scientific Results; Frey, F.A., Coffin, M.F., Wallace, P.J., Quilty, P.G., Eds.; Ocean Drilling Program: College Station, TX, USA, 2003; Volume 183, pp. 1-59.

81. Faris, M.; Farouk, S. Integrated biostratigraphy of two Upper Maastrichtian-Paleocene successions in north-central Sinai, Egypt. Geol. Croat. 2012, 65/2, 139-160. [CrossRef]

82. Dinarès-Turell, J.; Baceta, J.I.; Bernaola, G.; Orue-Etxebarria, X.; Pujalte, V. Closing the Mid-Palaeocene gap: Toward a complete astronomically tuned Palaeocene Epoch and Selandian and Thanetian GSSPs at Zumaia (Basque Basin, W Pyrenees). Earth Planet Sci. Lett. 2007, 262, 450-467. [CrossRef]

83. Ali, M.Y. High resolution calcareous nannofossil biostratigraphy and paleoecology across the Latest Danian Event (LDE) in central Eastern Desert, Egypt. Mar. Micropaleontol. 2009, 72, 111-128.

84. Wei, W.; Wise, S.W., Jr. Paleogene calcareous nannofossil magnetobiochronology: Results from South Atlantic DSDP site 616. Mar. Micropaleontol. 1989, 14, 119-152. [CrossRef]

85. Tantawy, A.A. Stratigraphical and Paleoecological Studies on Some Paleocene-Eocene Successions in Egypt. Unpub. Ph.D. Thesis, South Valley University, Quena, Egypt, 1998; 273p. 
86. Faris, M.; Abdel Hameed, A.T.; Shaaban, M. Calcareous nannofossil events at the Cretaceous/Paleocene boundary in central Egypt. In Proceedings of the 1st International Conference on the Geology of Africa, Assiut, Egypt, 23 November 1999; Volume 2, pp. 21-42.

87. Bukry, D.; Percival, S.F. New Tertiary calcareous nannofossils. Tulane Stud. Geol. Paleontol. 1971, 8, $123-146$.

88. Marzouk, A.M.; Luning, S. Comparative biostratigraphy of calcareous nannofossils and planktonic foraminifera in the Paleocene of the Eastern Sinai, Egypt. Neues Jahrb. Geol. Paläontologie 1998, 207, 77-105. [CrossRef]

89. Clemmensen, A.; Thomsen, E. Palaeoenvironmental changes across the Danian-Selandian boundary in the North Sea Basin. Palaeogeogr. Palaeoclimatol. Palaeoecol. 2005, 219, 351-394. [CrossRef]

90. Westerhold, T.; Röhl, U.; Donner, B.; McCarren, H.K.; Zachos, J. A complete high-resolution Paleocene benthic stable isotope record for the central Pacific (ODP Site 1209). Paleoceanography 2011, 26, PA2216. [CrossRef]

91. Aubry, M.-P.; Bord, D.; Rodriguez, O. New taxa of the Order Discoasterales Hay 1977. Micropaleontology 2011, 57, $269-287$.

92. Faris, M.; Abu Shama, A.M. Nannofossil biostratigraphy of the Paleocene lower Eocene succession in the Thamad area, east central Sinai, Egypt. Micropaleontology 2007, 53, 127-144. [CrossRef]

93. Faris, M.; Ayyad, S.N.; El Nahass, H.A.; Al Wosabi, K. Early Palaeogene stages and their boundaries in Sinai, Egypt. In Proceedings of the Fourth International Conference on the Geology of Africa, Assiut, Egypt, 15-16 November 2005; Volume 2, pp. 753-768.

94. Berggren, W.A.; Aubry, M.-P.; van Fossen, M.; Kent, D.V.; Norris, R.D.; Quillevere, F. Integrated Paleocene calcareous plankton magnetobiochronology and stable isotope stratigraphy: DSDP Site 384 (NW Atlantic Ocean). Palaeogeogr. Palaeoclimatol. Palaeoecol. 2000, 159, 1-51. [CrossRef]

95. Tantawy, A.A.; Ouda, K.; Von Salis, K.; El-Din, M.S. Biostratigraphy of Paleocene sections in Egypt. GFF 2000, 122, 163-165. [CrossRef]

96. Zachos, J.C.; Kroon, D.; Blum, P.; Bowles, J.; Gaillot, P.; Hasegawa, T.; Hathorne, E.C.; Hodell, D.A.; Kelly, D.C.; Jung, J.H.; et al. Early Cenozoic extreme Climates: The Walvis Ridge transect, Proceedings of the Ocean Drilling Program, Initial reports Leg 208. Proc. Ocean Drill. Program Initial Rep. 2004, 208, 1-117.

97. Bernaola, G.; Nuño-Arana, Y. Calcareous nannofossil assemblages across the mid-Paleocene. In The Paleocene and Lower Eocene of the Zumaia Section (Basque Basin). Climate and Biota of the Early Paleogene 2006; Post conference Field Trip Guidebook; University of the Basque Country: Bilbao, Spain; pp. 44-46.

98. Aubry, M.-P. Paleogene calcareous nannofossils from the Kerguelen Plateau, Leg 120. In Proceedings of the Ocean Drilling Program, Scientific Results; Ocean Drilling Program: College Station, TX, USA, 1992; Volume 120, pp. 471-491.

99. Agnini, C.; Fornaciari, E.; Rio, D.; Tateo, F.; Backman, J.; Giusberti, L. Responses of calcareous nannofossil assemblages, mineralogy and geochemistry to the environmental perturbations across the Paleocene/Eocene boundary in the Venetian Pre-Alps. Mar. Micropaleontol. 2007, 63, 19-38. [CrossRef]

100. Bown, P.R.; Pearson, P. Calcareous plankton evolution and the Paleocene/Eocene thermal maximum event: New evidence from Tanzania. Mar. Micropaleontol. 2009, 71, 60-70. [CrossRef]

101. Aubry, M.-P. Early Paleogene calcareous nannoplankton evolution: A tale of climatic amelioration. In Late Paleocene-Early Eocene Biotic and Climatic Events in the Marine and Terrestrial Record; Aubry, M.-P., Ouda, K., Eds.; Columbia University Press: New York, NY, USA, 1998; pp. 158-201.

102. Kahn, A.; Aubry, M.-P. Provincialism associated with the Paleocene/Eocene Thermal Maximum: Temporal constraint. Mar. Micropaleontol. 2004, 52, 117-132. [CrossRef]

103. Haq, B.U.; Lohmann, G.P.; Wise, S.W. Calcareous nannoplankton biogeography and its paleoclimatic implications: Cenozoic of Falkland Plateau (DSDP Leg 36) and Miocene of the Atlantic Ocean. Initial Rep. Deep Sea Drill. Proj. 1976, 36, 745-760.

104. Wise, S.W., Jr.; Wind, F.H. Mesozoic and Cenozoic calcareous nannofossils recovered by DSDP Leg 36 drilling on the Falkland Plateau, southwest Atlantic sector of the Southern Ocean. Proc. Deep Sea Proj. Initial Rep. 1977, 36, $269-491$.

105. Pospichal, J.; Wise, S.W., Jr. Paleocene to middle Eocene calcareous nannofossils of ODP Sites 689 and 690, Maud Rise, Weddell Sea. In Ocean Drilling Program, Scientific Results, 113Ocean Drilling Program; Barker, P.R., Kennett, J.P., Eds.; Ocean Drilling Program: College Station, TX, USA, 1990; pp. 613-638.

106. Firth, J.V.; Wise, S.W., Jr. A preliminary study of the evolution of Chiasmolithus in the Middle Eocene to Oligocene of Sites 647 and 748, ODP Leg 120. In Ocean Drilling Program Scientific Results; Ocean Drilling Program: College Station, TX, USA, 1992; Volume 120, pp. 493-508.

107. Mutterlose, J.; Linnert, C.; Norris, R. Calcareous nannofossils from the Paleocene-Eocene thermal maximum of the equatorial Atlantic (ODP Site 1260B): Evidence for tropical warming. Mar. Micropaleontol. 2007, 65, 13-31. [CrossRef]

108. Worsley, T.R. The Cretaceous-Tertiary boundary event. In Studies in Paleoceanography; SEPM Special Publication; Hay, W.W., Ed.; SEPM: Broken Arrow, OK, USA, 1974; Volume 20, pp. 94-125.

109. Jiang, M.J.; Gartner, S. Calcareous nannofossil succession across the Cretaceous-Tertiary boundary in east-central Texas. Micropaleontology 1986, 32, 232-255. [CrossRef]

110. Eshet, Y.; Moshkovitz, S.; Habib, D.; Benjamini, C.; Margaritz, M. Calcareous nannofossil and dinoflagellate stratigraphy across the Cretaceous/Tertiary boundary at Hor Hahar, Israel. Mar. Micropaleontol. 1992, 18, 199-228. [CrossRef]

111. Pospichal, J.J. Cretaceous/Tertiary Boundary Calcareous Nannofossils from Agost, Spain. In Proceedings of the 5th INA Conference in Salamanca, Salmanaca, Spain, September 1993; Flores, J.A., Sierro, F.J., Eds.; Universidad de SalamancaPress: Salamanca, Spain, 1995; pp. 185-217. 
112. Lamolda, M.A.; Mihaela, C.; Melinte, M.C.; Kaiho, K. Nannofloral extinction and survivorship across the K/T boundary at Caravaca, southeastern Spain. Palaeogeogr. Palaeoclimatol. Palaeoecol. 2005, 224, 27-52. [CrossRef]

113. Tantawy, A.A. Calcareous Nannofossils across the Cretaceous-Tertiary Boundary at Brazos, Texas, U.S.A.: Extinction and Survivorship, Biostratigraphy, and Paleoecology. In The End-Cretaceous Mass Extinction and the Chicxulub Impact in Texas; SEPM Special Publication 100, Keller, G., Adatte, T., Eds.; SEPM: Tulsa, OK, USA, 2011; pp. 157-178.

114. Gardin, S. Late Maastrichtian to early Danian calcareous nannofossils at Elles (Northwest Tunisia). A tale of one million years across the K-T boundary. Palaeogeogr. Palaeoclimatol. Palaeoecol. 2002, 178, 211-231. [CrossRef]

115. Abdel-Hameed, A.T.; Faris, M. Changes of relative surface water temperature throughout the Maastrichtian-Ypresian in Central Egypt. MERC Ain Shams Uni. Earth Sci. 1984, 1-16.

116. Tremolada, F.; Erba, E.; Bralower, T.J. A review of calcareous nannofossil changes during the early Aptian oceanic anoxic event 1a and the Paleocene-Eocene thermal maximum: The influence of fertility, temperature, and pCO2. In Large Ecosystem Perturbations: Causes and Consequences; Monechi, S., Coccioni, R., Rampino, M.R., Eds.; Geolical Society of America: Boulder, CO, USA, 2007; Volume 424, pp. 87-96.

117. Agnini, C.; Muttoni, G.; Kent, D.V.; Rio, D. Eocene biostratigraphy and magnetic stratigraphy from Possagno, Italy: The calcareous nannofossil response to climate variability, Earth. Planet. Sc. Lett. 2006, 241, 815-830. [CrossRef]

118. Gibbs, S.J.; Bown, P.R.; Sessa, J.A.; Bralower, T.J.; Wilson, P.A. Nannoplankton extinction and origination across the PaleoceneEocene Thermal Maximum. Science 2006, 314, 1770-1773. [CrossRef] [PubMed]

119. Erba, E. Nannofossils and superplumes: The early Aptian "nannoconid crisis". Paleoceanography 1994, 9, 483-501. [CrossRef] 